\title{
A brief bibliometric analysis of Web of Science publications on "Carbon" topic for 2019-2020
}

\author{
B.N. Chigarev \\ Oil and Gas Research Institute, Russian Academy of Sciences, Moscow \\ E-mail: bchigarev@ipng.ru
}

\begin{abstract}
A brief bibliometric analysis of 5,000 most cited scientific publications presented in the Web of Science database on the "Carbon" topic for 2019-2020 is done. It is shown that the world's leading scientific centers of China, the United States, India, South Korea, Japan and Germany, as well as the Russian Academy of Sciences are involved in research on this topic. The following areas of scientific research were dominant: materials science, physical chemistry, nanotechnology, engineering chemistry, applied physics, energy, electrochemistry, ecology, condensed matter physics.

The clustering method based on the co-occurrence of the Author Keywords and the Keywords Plus of the Web of Science system revealed six areas of research: 1. catalysis, hydrogen production, carbon materials doped with nitrogen; 2 . graphite/graphene-based energy storage systems; 3 . sensors and emissions based on carbon quantum dots; 4 . nanocomposites and their physical properties; 5 . energy consumption and climate change; 6 . adsorption and organic pollutants.

The author assumes the high potential of research on the co-production of hydrogen and graphite, which may combine the interests of hydrogen energy development and production of new materials.
\end{abstract}

Keywords: bibliometric analysis, Web of Science, scientometrics, carbon, graphene, hydrogen, catalysis, nanocomposites, energy storages.

Citation: Chigarev B.N. A brief bibliometric analysis of Web of Science publications on "Carbon" topic for 2019-2020 // Actual Problems of Oil and Gas. 2021. Iss. 2(33). P. 76-100. https://doi.org/10.29222/ ipng.2078-5712.2021-33.art6

\section{Introduction}

The Paris Climate Agreement aims to keep global warming well below two degrees Celsius, which imposes limits on greenhouse gas emissions ${ }^{1}$.

On the other hand, the United Nations Sustainable Development Goal 7 (SDG7) implies universal access to affordable, reliable, sustainable and modern energy sources ${ }^{2}$. The energy sector (electricity, heat and transport) is responsible for $73.2 \%$ of greenhouse gas emissions ${ }^{3}$.

A compromise in solving these problems can be achieved by co-producing hydrogen and carbon from fossil energy sources, which does not

\footnotetext{
${ }^{1}$ The Paris Agreement. https://unfccc.int/process-andmeetings/the-paris-agreement/the-paris-agreement ${ }^{2}$ Goal 7: Affordable and clean energy. https://www.un.org/sustainabledevelopment/energy/ ${ }^{3}$ Sector by sector: where do global greenhouse gas emissions come from? https://ourworldindata.org/emissions-by-sector
}

require the utilization of carbon dioxide $\left(\mathrm{CO}_{2}\right)$, especially from natural gas.

For example, the leading corporations of Russia's fuel and energy sector consider methane pyrolysis technology a promising way to enable the production of hydrogen and pure carbon ${ }^{4}$.

While the subject of hydrogen economy is well researched [1-3], the "production of materials based on carbon" direction is underrepresented in oil and gas studies. Thus, the query "carbon" in OnePetro, the online library of technical literature for the oil and gas industry, gets 17,327(2,702) publications for 2011-2020, while the query "carbon dioxide" OR "carbon capture" gets 7,080(1,175) papers, and the queries "carbon nanotube" and "graphene" get only 205 and 249(42) results respectively.

\footnotetext{
${ }^{4}$ Russia in the global hydrogen race. https://www.swpberlin.org/en/publication/russia-in-the-global-hydrogenrace/
} 
The number in parentheses refers to the articles in peer-reviewed journals. For comparison, in the Web of Science Core Collection, the queries: TOPIC: ("carbon nanotube") and TOPIC: (graphene) get 125,350 and 217,689 results for the given years respectively.

To reduce the biases associated with a single abstract database and a broad query, TOPIC, I present for comparison the data of The Lens database by the narrow queries: "Filters: Year Published $=(2011-2020)$ Keyword $=$ (Carbon Nanotubes)" obtains 2,624 records, while "Keyword = (Graphene)" obtains 5,783 records for the same period. To illustrate the topics of publications, I present graphs of the data in the "Fields of Study" and "Subject" fields for each of the queries (Fig. 1, 2).

a

\begin{tabular}{l}
2,407 \\
Carbon nanotube \\
7,168 \\
Materials science \\
\hline
\end{tabular}

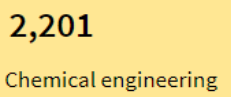

1,909

Nanocomposite

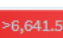

b

\begin{tabular}{|c|c|c|c|c|}
\hline $\begin{array}{l}833 \\
\text { Bioengineering }\end{array}$ & $\begin{array}{l}\text { 1,013 } \\
\text { Biomaterials }\end{array}$ & $\begin{array}{l}865 \\
\text { Biotechnology }\end{array}$ & $\begin{array}{l}903 \\
\text { Condensed Matter } \\
\text { Physics }\end{array}$ & $\begin{array}{l}1,880 \\
\text { General Chemistry }\end{array}$ \\
\hline $\begin{array}{l}\text { 3,985 } \\
\text { General Materials Science }\end{array}$ & $\begin{array}{l}1,072 \\
\text { General Medicine }\end{array}$ & $\begin{array}{l}797 \\
\text { General Physics and } \\
\text { Astronomy }\end{array}$ & $\begin{array}{l}1,315 \\
\text { Mechanical Engineering }\end{array}$ & Mechanics of Materials \\
\hline
\end{tabular}

Fig. 1. Distribution of publication topics for the query "Keyword = (Carbon Nanotubes)" by the fields:

a

\begin{tabular}{l}
$\begin{array}{l}1,094 \\
\text { Chemical engineering }\end{array}$ \\
\hline 4,404 \\
Materials science \\
\hline
\end{tabular}

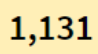

Chemistry

517

Nanocomposite

2,053
Chemistry
3,339
Nanotechnology

1,206

Composite material

995

Optoelectronics

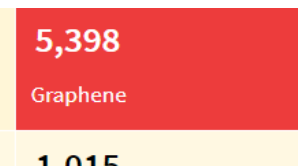

1,015

Oxide

\section{a - "Fields of Study", b - "Subject"}

\section{b}

\begin{tabular}{|c|c|c|c|c|}
\hline $\begin{array}{l}603 \\
\text { Bioengineering }\end{array}$ & $\begin{array}{l}556 \\
\text { Biomaterials }\end{array}$ & $\begin{array}{l}548 \\
\text { Biotechnology }\end{array}$ & $\begin{array}{l}662 \\
\text { Condensed Matter } \\
\text { Physics }\end{array}$ & $\begin{array}{l}1,272 \\
\text { General Chemistry }\end{array}$ \\
\hline $\begin{array}{l}501 \\
\text { General Engineering }\end{array}$ & $\begin{array}{l}2,728 \\
\text { General Materials Science }\end{array}$ & $\begin{array}{l}543 \\
\text { General Medicine }\end{array}$ & $\begin{array}{l}567 \\
\text { General Physics and } \\
\text { Astronomy }\end{array}$ & $\begin{array}{l}950 \\
\text { Mechanical Engineering }\end{array}$ \\
\hline
\end{tabular}

Fig. 2. Distribution of publication topics for the query "Keyword = (Graphene)" by the fields: a - "Fields of Study", b - "Subject"

In any data slice, the dominant topics are materials science, graphene, carbon nanotubes, nanotechnology, condensed state physics and composites. 
Such a huge number of peer-reviewed publications on the above queries aligns well with industry needs; for example, the carbon fiber market is expected to grow from $\$ 4.7$ billion in 2019 to $\$ 13.3$ billion by 2029 , at an average annual growth rate of $11.0 \%$ over the period from 2019 to $2029^{5}$.

The global graphene market was estimated at $\$ 78.7$ million in 2019 and is expected to grow at a compound annual growth rate of $38.7 \%$ from 2020 to $2027^{6}$.

For the Russian fuel and energy sector, the rapidly developing market for carbon-based materials can be of great interest, so it is advisable to analyze the picture of scientific research on this topic.

\section{Materials}

To build an overall picture of carbon-related scientific publications and to reduce selection biases, bibliometric data from the Web of Science (WoS) reference database were retrieved by the most general query:

TITLE: (carbon) and Timespan: 2019-2020 and Indexes: SCI-EXPANDED, ESCI.

A total of 58,924 results were obtained at the time of the query (28.10.2020). For further bibliometric analysis, I selected 5,000 most cited publications. At the same time, the bulk of the publications $-4,598$ articles - falls on 2019, the papers of 2020 are not indexed in full, so the citation can only be evaluated later.

The choice of the base query was derived from the analysis of the test query data. The total number of publications indexed in the WoS for 2011-2020 for the query "carbon* OR graphene*" was:

\footnotetext{
${ }^{5} \mathrm{Global}$ carbon fiber market size.

https://www.whatech.com/markets-research/materialschemicals/705441-carbon-fiber-market-by-raw-materialpan-pitch-rayon-fiber-type-virgin-recycled-product-typemodulus-application-composite-non-composite-end-useindustry

${ }^{6}$ Graphene market size.

https://www.grandviewresearch.com/industryanalysis/graphene-industry
}

$-1,125,785$ publications when searching by all fields of the database;

$-1,074,048$ documents when searching by the titles, Author Keywords and Keywords Plus (the index terms generated by the WoS by in-depth analysis of the references of the articles).

$-381,641$ publications when narrowing the search to the presence of "carbon* OR graphene*" only in the titles.

By removing "graphene*" from the query, I reduced the focus of interest on a specific type of material, by limiting the time interval to 20192020, I focused the interest on recent publications, which corresponds to the main objective of this paper: to analyze the current landscape of scientific publications on the topic "Carbon".

The data from The Lens platform were additionally used to demonstrate the independence of the obtained results from the chosen abstract database.

\section{Methods}

Following the aim of this study - to build the overall picture of carbon-related scientific publications - I used only bibliometric methods for assessing the co-occurrence of the sum of Author Keywords and Keywords Plus (clustering), as well as some data from the "Analysis of results" section of the WoS. For keyword clustering, I used the VOSviewer scientometric and bibliometric software [4, 5]. The total number of unique keywords in 5,000 publications were 18,985, with 975 words occurring more than nine times. The parameter of the minimum number of words in the cluster was chosen to be 100 . The stability of clustering was checked by changing this parameter by $\pm 20 \%$. This resulted in the identification of six clusters.

Keywords and other terms in the tables are given as they appear in the bibliometric data, enabling to use them in a further selection of materials by subject specialists.

For each cluster, I give examples of references to highly cited publications that illustrate the subject of this cluster well. 


\section{General bibliometric data on $\mathbf{5 8 , 9 2 4}$ publications}

The processing of 58,924 bibliometric data gathered by the query: "TITLE: (carbon) and
Timespan: 2019-2020 and Indexes: SCIEXPANDED, ESCI" revealed the distribution of publication activity by country and source of funding (Table 1).

Distribution of publication activity by country and funding sources

\begin{tabular}{|l|c|l|c|}
\hline \multicolumn{1}{|c|}{ Countries } & Records & \multicolumn{1}{|c|}{ Funding Agencies } & Records \\
\hline Peoples R China & 26,488 & National Natural Science Foundation of China NSFC & 18,356 \\
\hline USA & 8,167 & Fundamental Research Funds for the Central Universities & 2,938 \\
\hline India & 3,610 & National Key Research and Development Program of China & 1,688 \\
\hline South Korea & 2,985 & China Postdoctoral Science Foundation & 1,679 \\
\hline Japan & 2,778 & National Science Foundation NSF & 1,569 \\
\hline Germany & 2,663 & National Key R\&D Program of China & 1,234 \\
\hline Iran & 2,213 & Ministry of Education Culture Sports Science and Technology Japan MEXT & 1,032 \\
\hline England & 2,183 & European Union EU & 922 \\
\hline Australia & 2,155 & Japan Society for the Promotion of Science & 880 \\
\hline Canada & 1,590 & United States Department of Energy DOE & 865 \\
\hline Russia & 1,575 & Natural Science Foundation of Jiangsu Province & 798 \\
\hline France & 1,555 & China Scholarship Council & 790 \\
\hline Spain & 1,411 & National Council for Scientific and Technological Development CNPG & 703 \\
\hline Italy & 1,263 & Australian Research Council & 641 \\
\hline Brazil & 1,247 & Chinese Academy of Sciences & 641 \\
\hline Saudi Arabia & 950 & CAPES & 633 \\
\hline Turkey & 910 & German Research Foundation DFG & 626 \\
\hline Taiwan & 897 & Natural Science Foundation of Shandong Province & 615 \\
\hline Malaysia & 852 & Natural Sciences and Engineering Research Council of Canada & 595 \\
\hline Poland & 838 & Grants-in-Aid for Scientific Research (KAKENHI) & 586 \\
\hline
\end{tabular}

Table 1 indicates that the dominance of carbon-related publications from China correlates well with the list of funders, which are also predominantly Chinese. India has good publication activity, largely due to extensive collaboration with other countries. The US and European researchers also rely on good funding: National Science Foundation; European Union; United States Department of Energy (DOE); German Research Foundation. Research in Japan is supported by Ministry of Education, Culture, Sports Science and Technology Japan (MEXT) and Grants-in-Aid for Scientific Research (KAKENHI).

The fact that Russia occupies an intermediate position between Canada and France indicates that Russian researchers pay considerable attention to the topic in question. Two factors should be taken into account: less involvement of Russian research institutions in international cooperation compared to the institutions of China, the United States and Europe, and the fact that a significant part of the research results is published in Russian-language journals that are not indexed in the Web of Science.

Worth noting is the high publication activity of Iran, which is under stronger sanctions than Russia but is better represented in the publications in highly ranked journals.

Most frequent are the publications in these seven languages (of the total number of 58,924): English (58,147); Chinese (333); Spanish (77); Korean (76); Russian (67); German (66); Japanese (44). 
Further, I analyzed the distribution of publication activity by the WoS categories and journal titles (Table 2). Table 2 indicates that the WoS categories are dominated by sections related to materials science, chemistry, condensed state physics, metallurgy, polymers, nanotechnology and energy. The journal titles in the second column of the table agree well with the WoS categories, with journals publishing articles on various topics in chemistry and materials science predominating. Of particular note is the International Journal of Hydrogen Energy (h-index=202), which is the official publication of the International Association for Hydrogen Energy. Sections on "hydrogen fuel cells", "electrolysis of water to produce hydrogen" and "hydrogen storage using nanomaterials" all involve the development of new materials based on various forms of graphite.

Distribution of publication activity by the WoS categories and journal titles

\begin{tabular}{|l|c|l|c|}
\hline \multicolumn{1}{|c|}{ WoS categories } & Records & \multicolumn{1}{|c|}{ Source titles } & Records \\
\hline Materials Science Multidisciplinary & 14,171 & Carbon (Q1) & 734 \\
\hline Chemistry Physical & 10,243 & Chemical Engineering Journal (Q1) & 732 \\
\hline Chemistry Multidisciplinary & 7,808 & Applied Surface Science (Q1) & 722 \\
\hline Environmental Sciences & 6,499 & Electrochimica Acta (Q1) & 693 \\
\hline Nanoscience Nanotechnology & 5,323 & ACS Applied Materials Interfaces (Q1) & 672 \\
\hline Engineering Chemical & 5,186 & Journal of Cleaner Production (Q1) & 645 \\
\hline Physics Applied & 5,030 & Science of the Total Environment (Q1) & 639 \\
\hline Energy Fuels & 4,841 & Journal of Alloys and Compounds (Q1) & 622 \\
\hline Electrochemistry & 3,856 & Journal of Materials Chemistry A (Q1) & 552 \\
\hline Engineering Environmental & 3,088 & RSC Advances (Q2) & 487 \\
\hline Physics Condensed Matter & 3,023 & ACS Sustainable Chemistry Engineering (Q1) & 485 \\
\hline Chemistry Analytical & 2,514 & Abstracts of Papers of the American Chemical Society & 451 \\
\hline Green Sustainable Science Technology & 2,302 & International Journal of Hydrogen Energy (Q2) & 443 \\
\hline Metallurgy Metallurgical Engineering & 1,885 & Environmental Science and Pollution Research (Q2) & 441 \\
\hline Polymer Science & 1,822 & Scientific Reports (Q1) & 439 \\
\hline Multidisciplinary Sciences & 1,632 & Journal of Colloid and Interface Science (Q1) & 403 \\
\hline Materials Science Coatings Films & 1,589 & Materials (Q2) & 378 \\
\hline Materials Science Composites & 1,566 & Journal of Power Sources (Q1) & 354 \\
\hline Geosciences Multidisciplinary & 1,112 & Nanoscale (Q1) & 337 \\
\hline Soil Science & 1,059 & Nanomaterials (Q1) & 4 \\
\hline
\end{tabular}

Note: Journal quartile membership was determined by the Journal Citation Reports category with the highest score in the WoS.

Ten organizations/affiliations with the highest publication activity are: Chinese Academy of Sciences (3897); University of Chinese Academy of Sciences CAS (1,394); Centre national de la recherche scientifique $(1,070)$; Russian Academy of Sciences (827); University of California System (800); United States Department of Energy (794); Indian Institute of Technology System (748); Tsinghua University (671); University of Science Technology of China (574); Helmholtz Association (569).

\section{Bibliometric analysis of the 5,000 most highly cited articles revealing the dominant areas of research}

Research topics are described well both by Author Keywords and by Keywords Plus generated by the WoS system (Table 3 ). Table 3 indicates that the most frequent are the keywords associated with graphene, carbon nanomaterials, graphene oxide, carbon nanotubes, nanocomposites and graphene quantum dots. 
The $\mathbf{4 0}$ most frequent keywords in 5,000 highly cited publications 2019-2020 (data retrieved 28.10.2020)

\begin{tabular}{|c|c|c|c|}
\hline Keyword & Occurrence & Keyword & Occurrence \\
\hline performance** & 804 & catalysts & 209 \\
\hline graphene* & 766 & carbon nanotubes* & 198 \\
\hline nanoparticles* & 669 & oxide & 195 \\
\hline nanosheets* & 500 & oxygen reduction reaction & 188 \\
\hline nitrogen & 361 & removal & 178 \\
\hline adsorption & 328 & supercapacitor*** & 178 \\
\hline porous carbon* & 318 & storage $* * *$ & 175 \\
\hline water & 316 & degradation & 170 \\
\hline nanotubes* & 315 & reduced graphene oxide & 165 \\
\hline composite & 314 & metal-organic frameworks & 163 \\
\hline composites & 284 & energy & 162 \\
\hline activated carbon & 278 & oxidation & 162 \\
\hline graphene oxide* & 258 & biomass & 161 \\
\hline facile synthesis & 254 & energy-storage $* * *$ & 161 \\
\hline nanocomposites* & 251 & quantum dots* & 161 \\
\hline efficient & 242 & nanocomposite* & 156 \\
\hline fabrication & 238 & graphene quantum dots* & 152 \\
\hline reduction & 227 & high-performance** & 150 \\
\hline electrode & 217 & oxygen reduction & 144 \\
\hline electrodes & 216 & behavior & 143 \\
\hline
\end{tabular}

Note: the single $\left({ }^{*}\right)$, double $\left({ }^{* *}\right)$ and triple $\left({ }^{* *}\right)$ asterisks indicate terms that might be conventionally assigned to the same cluster. For example: supercapacitor***, storage***, energy-storage***.

The keyword "performance" comes first in terms of frequency; the examples of phrases with it in the full texts are: catalytic performance, highperformance lithium-sulfur batteries, electromechanical performance, electrocatalytic performance, photocatalytic performance, electrochemical performance, storage performance, high-performance anode materials, high-performance composites. This indicates the high importance of the examined subject for applied research, which is also confirmed by such keywords as: manufacturing, supercapacitor, storage, degradation, metal-organic framework, energy accumulation.

\section{Clustering of keywords based on their co-occurrence in the 5,000 most cited publications}

For a detailed study of the "Carbon" topic, I used the clustering of keywords based on their cooccurrence in the 5,000 most cited publications.

VOSviewer, a program designed to build and visualize bibliometric data networks, was used for keyword clustering.

Keyword clustering (Author + KeyWords Plus) was performed under the following conditions: out of 18,985 keywords, 975 keywords were selected that occurred more than nine times, while each cluster included at least 100 keywords. 
Six clusters were obtained:

1. catalysis, hydrogen-production, nitrogendoped carbon;

2. graphite/graphene-based energy storage systems;

3. sensors and emissions based on carbon quantum dots;

4. nanocomposites and their physical properties;

5. energy consumption and climate change;

6. adsorption and organic pollutants.

Their main features are presented below in tables and graphs. The stability of clustering was checked by changing of the minimum number of keywords in the cluster by $\pm 20 \%$.

In compiling the summary tables for each of the six clusters, 40 of the most frequent keywords were selected and used to describe the cluster theme.
The tables contain the following fields: label (keyword name), keyword occurrence and the average citation of the publications in which this keyword appears.

It should be noted that the average citation of a keyword is determined by the average citation of the articles whose entries contain this term in the Author keywords and Keywords Plus fields. This value can be retrieved from the GML files generated by VOSViewer.

In addition to the tables, graphs of the relationships between terms are presented for the two most frequent terms in each cluster. Such data presentation makes it possible to demonstrate the relationship between terms not only within a cluster but also between clusters.

The results of the bibliometric analysis for the first cluster are presented in Table 4 and Fig. 3 and 4 .

Table 4

The $\mathbf{4 0}$ most frequent keywords within the Cluster 1 and the average citations of publications associated with a keyword

\begin{tabular}{|c|c|c|c|c|c|}
\hline Label & Occurrence & $\begin{array}{l}\text { Average } \\
\text { citations }\end{array}$ & Label & Occurrence & $\begin{array}{l}\text { Average } \\
\text { citations }\end{array}$ \\
\hline nitrogen^^ & 361 & 23.2 & electrocatalysis* & 88 & 26.0 \\
\hline water & 316 & 22.5 & iron & 86 & 20.9 \\
\hline facile synthesis & 254 & 23.5 & oxygen** & 85 & 23.0 \\
\hline efficient & 242 & 23.3 & $\mathrm{CO}_{2}$ reduction & 84 & 25.7 \\
\hline reduction & 227 & 21.2 & electrocatalyst* & 82 & 23.0 \\
\hline catalysts* & 209 & 22.9 & hydrogen evolution** reaction & 79 & 25.3 \\
\hline oxygen reduction** reaction & 188 & 26.4 & active-sites & 77 & 25.9 \\
\hline degradation & 170 & 20.0 & sulfur & 75 & 21.7 \\
\hline metal-organic frameworks & 163 & 25.0 & $\mathrm{TIO}_{2}$ & 74 & 17.7 \\
\hline oxidation** & 162 & 20.6 & construction & 71 & 24.9 \\
\hline oxygen reduction** & 144 & 25.1 & dioxide & 69 & 21.4 \\
\hline catalyst* & 140 & 20.6 & oxygen evolution reaction & 67 & 24.3 \\
\hline electrocatalysts* & 137 & 27.3 & $\mathrm{CO}$ & 66 & 19.7 \\
\hline evolution & 136 & 24.8 & nitrogen-doped carbon ${ }^{\wedge}$ & 64 & 23.0 \\
\hline highly efficient & 132 & 23.0 & doped carbon & 62 & 23.8 \\
\hline conversion & 130 & 21.0 & hydrogen** & 62 & 20.7 \\
\hline hydrogen evolution** & 130 & 30.5 & carbon nitride ${ }^{\wedge}$ & 58 & 27.3 \\
\hline metal-organic framework & 127 & 20.8 & g- $\mathrm{C}_{3} \mathrm{~N}_{4}$ nanosheets ${ }^{\wedge}$ & 58 & 22.9 \\
\hline photocatalysis* & 123 & 26.0 & graphitic carbon nitride $^{\wedge}$ & 58 & 23.5 \\
\hline $\mathrm{g}-\mathrm{C}_{3} \mathrm{~N}_{4} \wedge$ & 103 & 22.6 & N-doped carbon^^ & 58 & 22.5 \\
\hline
\end{tabular}

Note: Contextually related terms are marked by the symbols ${ }^{*}$ and ${ }^{* *}$. Nitrogen-related terms are marked by the symbol ${ }^{\wedge}$. 
This cluster can be conditionally labelled "Catalysis, hydrogen-production, nitrogen-doped carbon". Several categories of keywords correspond with this label: electrocatalysis, photocatalysis, hydrogen evolution, oxygen evolution reaction, as well as the most cited publications mentioning electro- and photocatalysis, hydrogen evolution [6, 7]; the keywords related to carbon nitride (carbon nitride, graphitic carbon nitride, nanosheets, $\mathrm{g}-\mathrm{C}_{3} \mathrm{~N}_{4}$ ) and the corresponding publications [8-11]. Noteworthy is the frequent mention of nitrogen-doped carbon, which is considered to be a promising type of cathode catalyst [12-15].

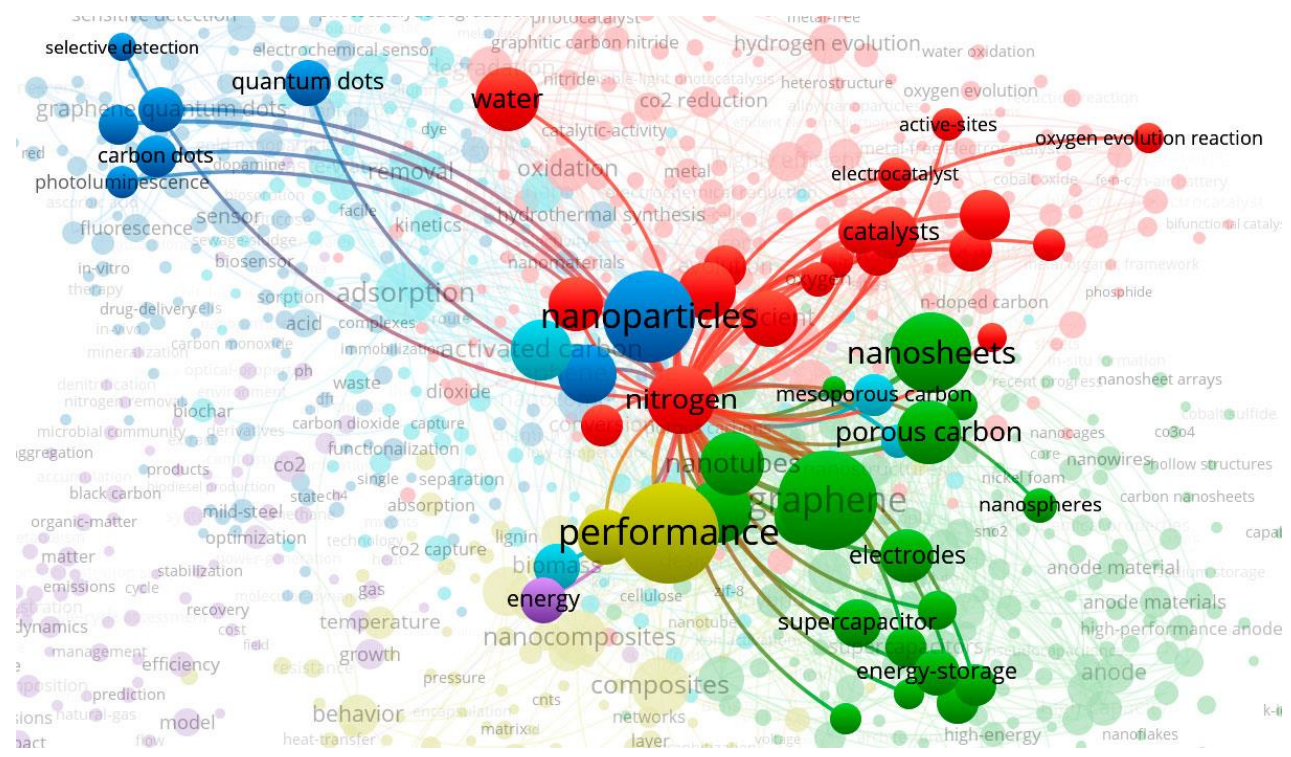

Fig. 3. Cluster 1. The main links of the term "nitrogen" with the other terms

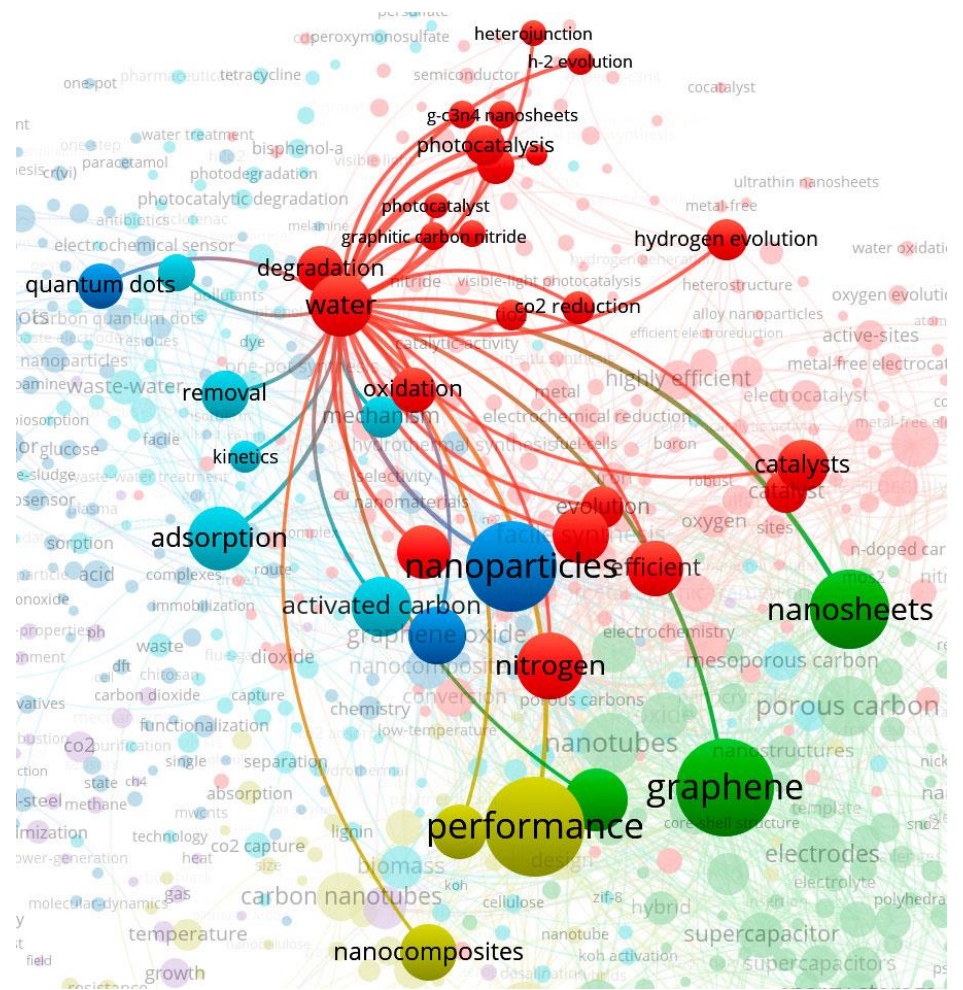

Fig. 4. Cluster 1. The main links of the term "water" with the other terms

The results of the bibliometric analysis for the second cluster are presented in Table 5 and Fig. 5 and 6. 
The 40 most frequent keywords within the Cluster 2

and the average citations of publications associated with a keyword

\begin{tabular}{|l|c|c|l|c|c|}
\hline \multicolumn{1}{|c|}{ Label } & Occurrence & $\begin{array}{c}\text { Average } \\
\text { citations }\end{array}$ & \multicolumn{1}{c|}{ Label } & Occurrence & $\begin{array}{c}\text { Average } \\
\text { citations }\end{array}$ \\
\hline graphene* & 766 & 22.0 & high-capacity** & 107 & 23.8 \\
\hline nanosheets* & 500 & 23.3 & lithium** & 107 & 23.2 \\
\hline porous carbon* & 318 & 23.9 & hybrid & 98 & 22.4 \\
\hline nanotubes* & 315 & 21.3 & nanostructures* & 94 & 23.6 \\
\hline composite & 314 & 21.6 & carbon & 89 & 23.0 \\
\hline electrode** & 217 & 22.5 & nanospheres* & 88 & 24.6 \\
\hline electrodes** & 216 & 23.8 & anode materials** & 82 & 25.1 \\
\hline oxide & 195 & 20.6 & batteries** & 80 & 24.5 \\
\hline supercapacitor** & 178 & 19.1 & capacity** & 80 & 22.3 \\
\hline storage** & 175 & 21.8 & arrays & 79 & 22.8 \\
\hline reduced graphene oxide & 165 & 22.7 & anode material** & 78 & 23.0 \\
\hline energy-storage** & 161 & 23.5 & spheres & 77 & 19.6 \\
\hline high-performance & 150 & 23.8 & capacitance** & 74 & 20.8 \\
\hline anode** & 132 & 22.6 & nanocrystals & 73 & 23.1 \\
\hline cathode** & 130 & 21.0 & sodium-ion batteries & 73 & 26.6 \\
\hline electrochemical performance** & 128 & 22.4 & doped graphene* & 69 & 27.7 \\
\hline supercapacitors** & 127 & 18.4 & graphite & 69 & 22.4 \\
\hline electrode materials** & 114 & 20.3 & $\begin{array}{l}\text { hierarchical porous } \\
\text { carbon }\end{array}$ & 67 & 19.0 \\
\hline nanofibers* & 114 & 24.8 & lithium-ion** & 64 & 23.5 \\
\hline microspheres & 27.4 & shell & 22.2 \\
\hline
\end{tabular}

Note: Contextually related terms are marked by the symbols * and **.

The conditional name for the cluster is "Graphite/graphene-based energy storage systems". Corresponding keywords: graphene, porous carbon, nanotubes, nanostructures, nano- particles, nanocrystals, doped graphene, electrode materials, anode, cathode, electrochemical characteristics, supercapacitors, high capacity, lithium, sodium-ion and lithium-ion batteries.

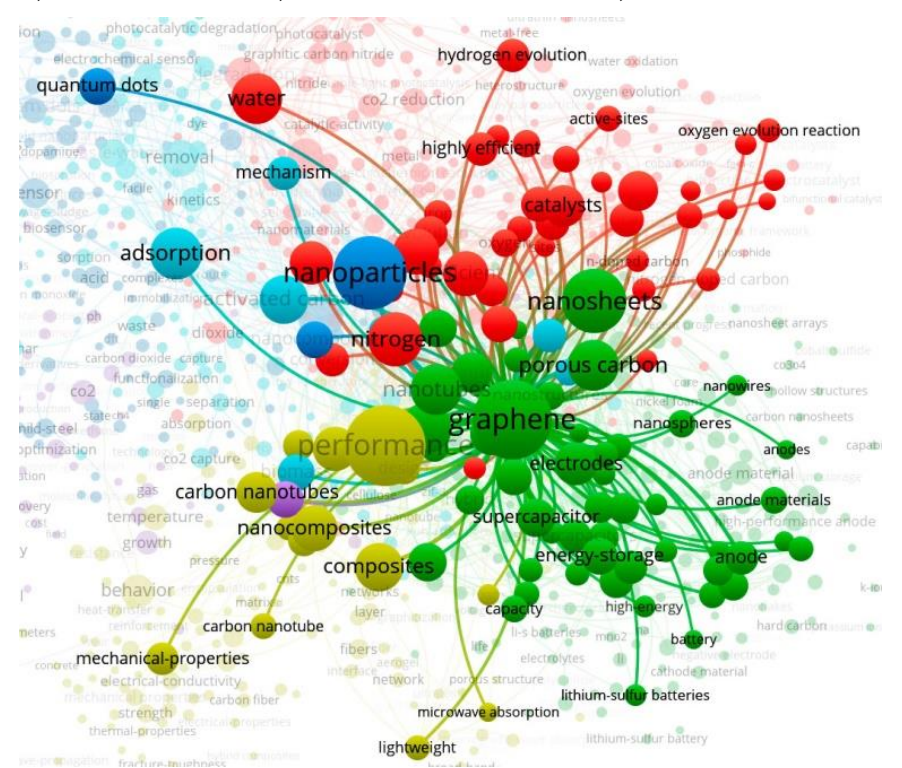

Fig. 5. Cluster 2. The main links of the term "graphene" with the other terms 


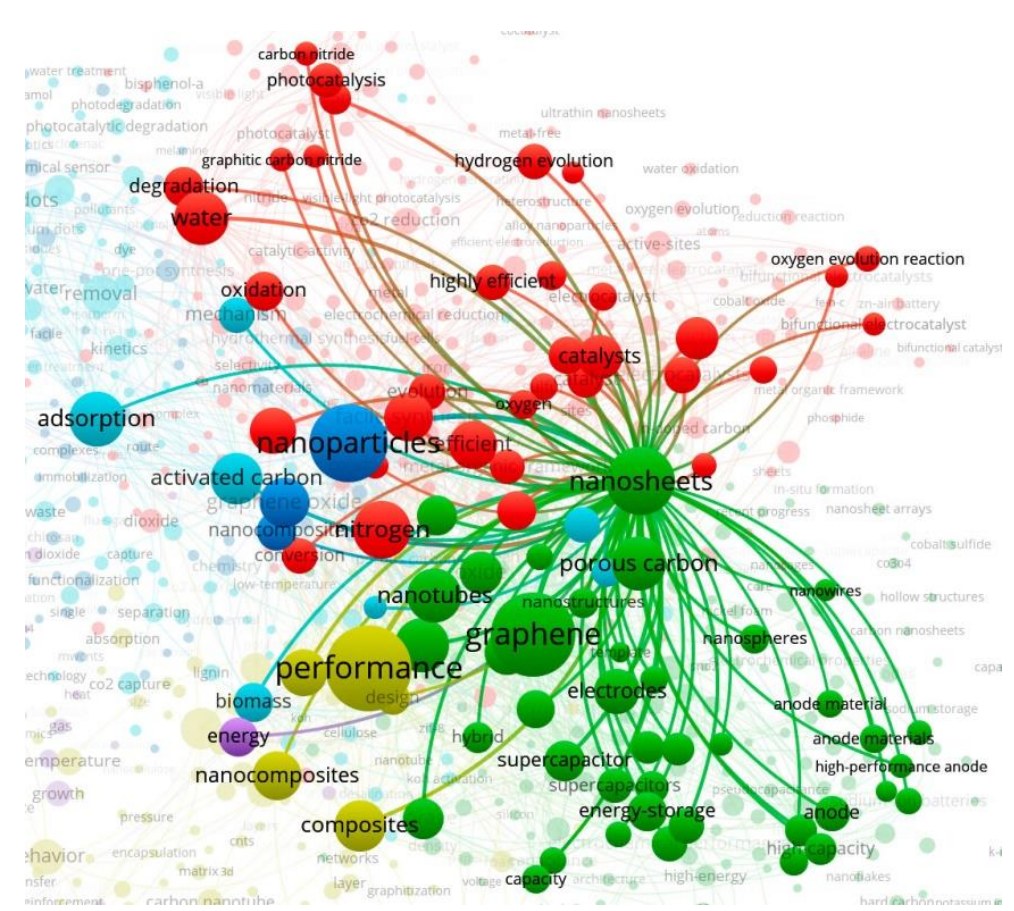

Fig. 6. Cluster 2. The main links of the term "nanosheets" with the other terms

This cluster is represented by the publications [16-21].

The results of the bibliometric analysis for the third cluster are presented in Table 6 and Fig. 7 and 8 .

The $\mathbf{4 0}$ most frequent keywords within the Cluster 3 and the average citations of publications associated with a keyword

\begin{tabular}{|c|c|c|c|c|c|}
\hline Label & Occurrence & $\begin{array}{l}\text { Average } \\
\text { citations }\end{array}$ & Label & Occurrence & $\begin{array}{l}\text { Average } \\
\text { citations }\end{array}$ \\
\hline nanoparticles & 669 & 20.4 & chemistry & 48 & 19.3 \\
\hline graphene oxide & 258 & 23.2 & mild-steel & 47 & 16.5 \\
\hline quantum dots* & 161 & 20.8 & green & 46 & 20.5 \\
\hline nanocomposite & 156 & 19.9 & emission & 45 & 16.2 \\
\hline graphene quantum dots* & 152 & 21.5 & functionalization & 44 & 20.0 \\
\hline carbon dots* & 130 & 19.4 & ions & 44 & 18.6 \\
\hline sensor** & 119 & 17.1 & biosensor** & 41 & 19.1 \\
\hline nanodots* & 115 & 18.2 & luminescence** & 41 & 19.5 \\
\hline green synthesis & 83 & 20.5 & hydrogen-peroxide & 40 & 18.4 \\
\hline photoluminescence** & 79 & 18.2 & electrochemical sensor** & 37 & 16.3 \\
\hline sensitive detection** & 73 & 19.6 & ascorbic-acid & 34 & 19.1 \\
\hline one-step synthesis & 67 & 31.0 & glucose & 33 & 17.9 \\
\hline acid & 66 & 18.2 & voltammetric determination** & 33 & 17.6 \\
\hline fluorescence** & 65 & 17.7 & probe** & 32 & 17.3 \\
\hline hydrothermal synthesis & 63 & 20.0 & label-free detection & 31 & 34.6 \\
\hline one-pot synthesis & 62 & 28.4 & dopamine & 30 & 16.8 \\
\hline carbon quantum dots* & 58 & 23.3 & extraction & 30 & 16.9 \\
\hline gold nanoparticles & 58 & 21.2 & sensors** & 30 & 17.9 \\
\hline selective detection** & 58 & 18.3 & complexes & 29 & 17.0 \\
\hline nanomaterials & 51 & 19.5 & derivatives & 29 & 15.7 \\
\hline
\end{tabular}

Note: Contextually related terms are marked by the symbols * and **. 
The conditional name for the cluster is "Sensors and emissions based on carbon quantum dots". Corresponding keywords: graphene/carbon quantum dots, nanodots, sensors, selective detection, biosensor, electrochemical sensors, voltammetric determination, probe, label-free detection, fluorescence, luminescence.

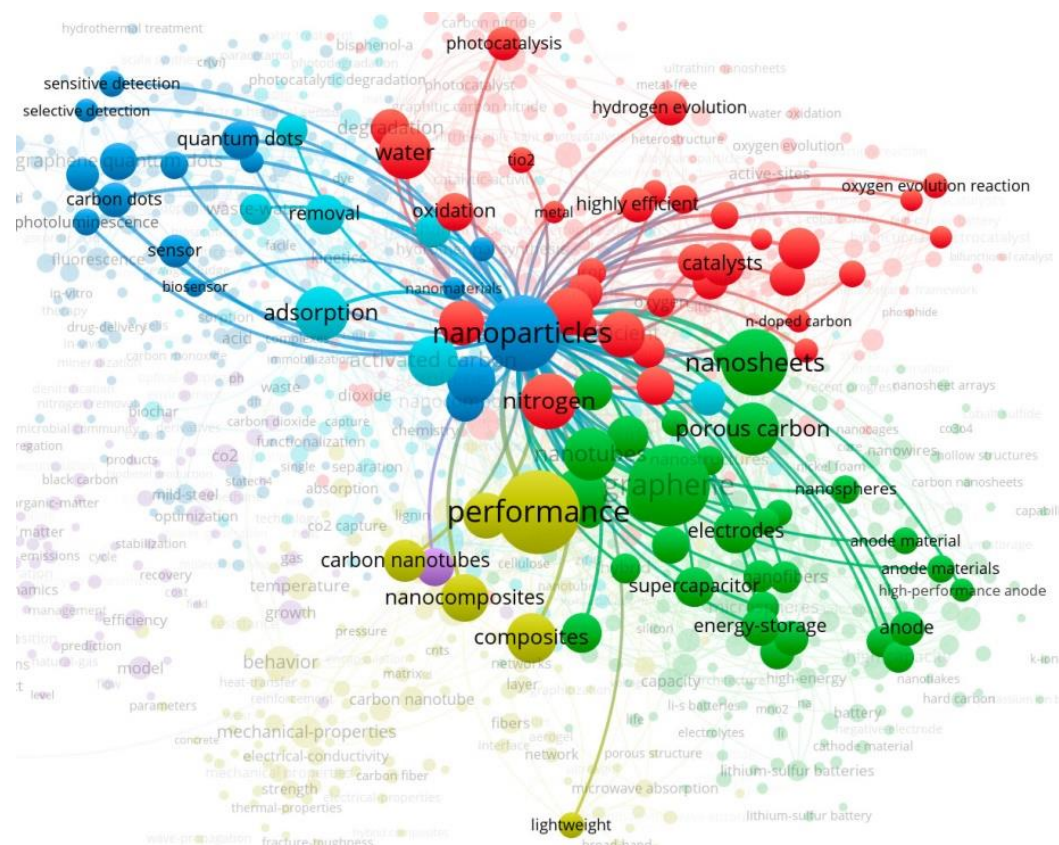

Fig. 7. Cluster 3 . The main links of the term "nanoparticles" with the other terms

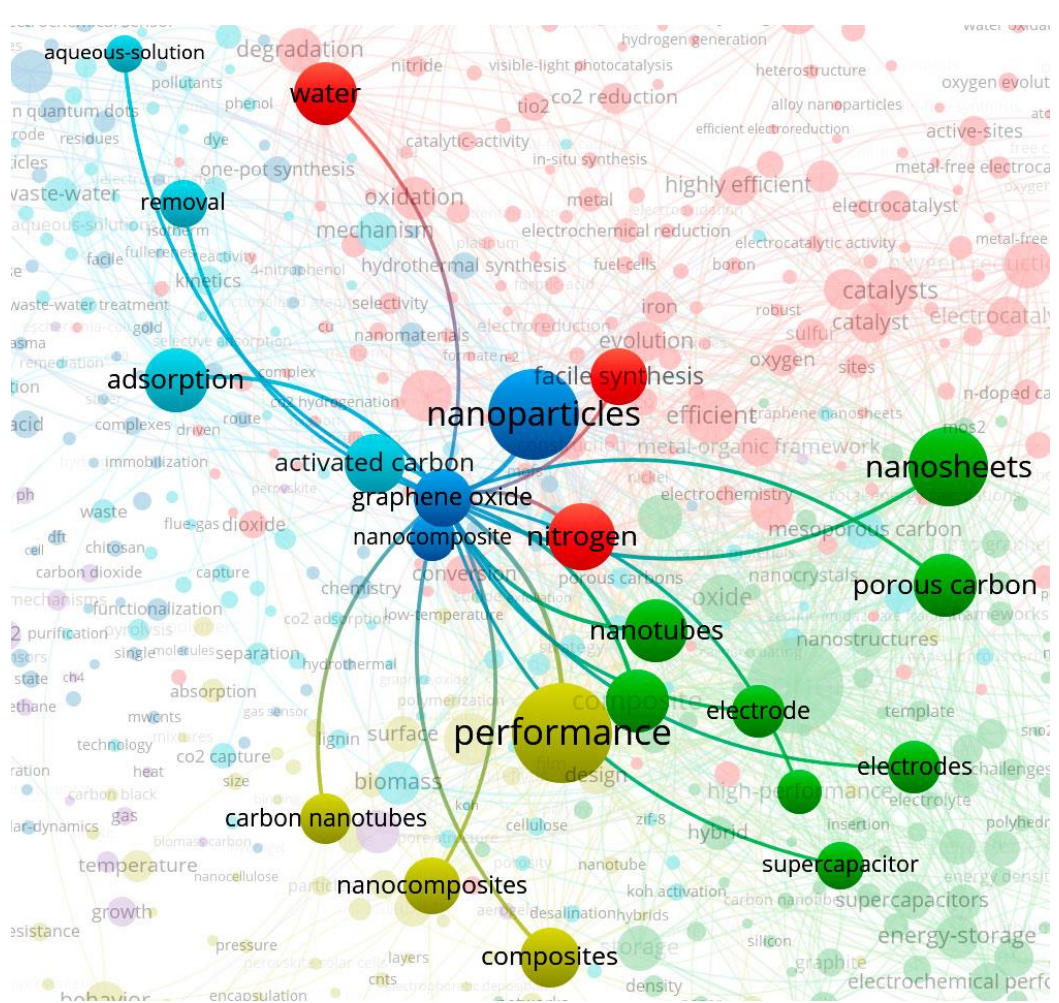

Fig. 8. Cluster 3. The main links of the term "graphene oxide" with the other terms

This cluster is represented by the publications [22-27].

The results of the bibliometric analysis for the fourth cluster are presented in Table 7 and Fig. 9 and 10. 
The $\mathbf{4 0}$ most frequent keywords within the Cluster 4

and the average citations of publications associated with a keyword

\begin{tabular}{|l|c|c|l|c|c|}
\hline \multicolumn{1}{|c|}{ Label } & Occurrence & $\begin{array}{c}\text { Average } \\
\text { citations }\end{array}$ & \multicolumn{1}{|c|}{ Label } & Occurrence & $\begin{array}{c}\text { Average } \\
\text { citations }\end{array}$ \\
\hline performance & 804 & 21.1 & electrical-conductivity** & 45 & 23.1 \\
\hline composites* $^{*}$ & 284 & 21.4 & microstructure** & 43 & 19.9 \\
\hline nanocomposites* & 251 & 22.0 & morphology** & 43 & 18.6 \\
\hline fabrication & 238 & 20.3 & strength** & 43 & 17.4 \\
\hline carbon nanotubes* & 198 & 20.9 & layer & 42 & 20.3 \\
\hline behavior** & 143 & 17.8 & mechanical properties** & 41 & 20.3 \\
\hline mechanical-properties** & 126 & 19.1 & networks & 41 & 23.0 \\
\hline design** & 121 & 21.5 & dispersion** & 40 & 16.3 \\
\hline stability** & 116 & 18.9 & microwave absorption** & 39 & 29.1 \\
\hline surface & 114 & 17.9 & deposition & 36 & 20.4 \\
\hline temperature** & 88 & 22.2 & particles & 35 & 18.1 \\
\hline carbon nanotube* & 78 & 16.3 & thermal-conductivity** & 34 & 22.4 \\
\hline lightweight & 72 & 25.5 & polymers* & 33 & 25.8 \\
\hline enhancement & 70 & 22.9 & network & 31 & 19.5 \\
\hline films & 68 & 22.6 & polymer composites* & 31 & 18.9 \\
\hline conductivity & 58 & 20.1 & resistance** & 31 & 19.4 \\
\hline fibers & 54 & 24.3 & thin-films & 31 & 24.0 \\
\hline foam & 53 & 20.2 & matrix & 30 & 22.0 \\
\hline polymer & 19.4 & surface modification** & 30 & 25.0 \\
\hline absorption & 21.0 & carbon fiber* & 17.4 \\
\hline
\end{tabular}

Note: Contextually related terms are marked by the symbols * and ${ }^{* *}$.

The conditional name for the cluster is "Nanocomposites and their physical properties". Corresponding keywords: composites, nanocomposites, carbon nanotubes, polymer composites, thin-films, carbon fiber, electrical properties, elastic properties, mechanical properties, thermal-properties, stability, surface, temperature, light weight, conductivity, absorption, electrical conductivity, microstructure, strength, electromagnetic-wave absorption, resistance, surface modification, fabrication, design.

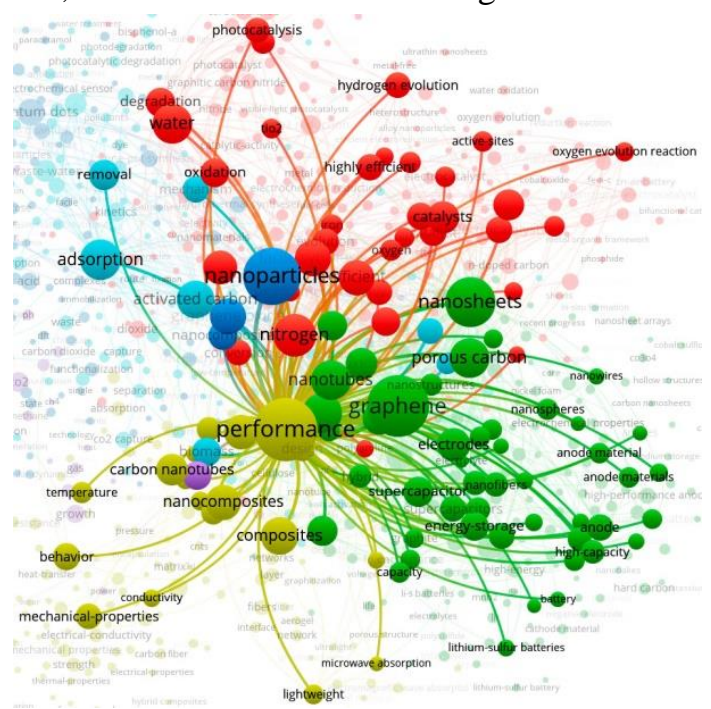

Fig. 9. Cluster 4. The main links of the term "performance" with the other terms 


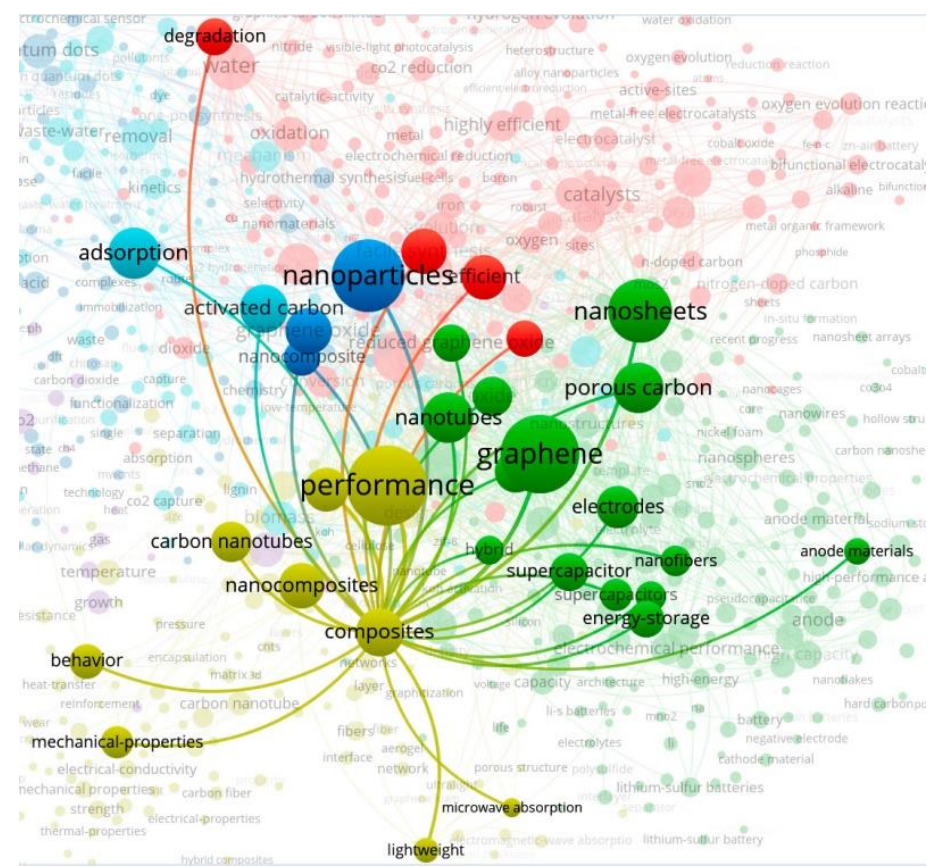

Fig. 10. Cluster 4. The main links of the term "composites" with the other terms

This cluster is represented by the publications [28-32].

The results of the bibliometric analysis for the fifth cluster are presented in Table 8 and Fig. 11 and 12 .

The $\mathbf{4 0}$ most frequent keywords within the Cluster 5

Table 8 and the average citations of publications associated with a keyword

\begin{tabular}{|c|c|c|c|c|c|}
\hline Label & Occurrence & $\begin{array}{l}\text { Average } \\
\text { citations }\end{array}$ & Label & Occurrence & $\begin{array}{l}\text { Average } \\
\text { citations }\end{array}$ \\
\hline energy* & 162 & 21.2 & matter & 34 & 19.0 \\
\hline $\mathrm{CO}_{2}$ emissions $* *$ & 115 & 22.4 & system & 34 & 17.8 \\
\hline $\mathrm{CO}_{2}^{* *}$ & 84 & 19.6 & greenhouse-gas** emissions & 33 & 15.9 \\
\hline growth & 75 & 21.3 & gas** & 31 & 16.4 \\
\hline model & 69 & 17.6 & sequestration & 31 & 16.2 \\
\hline energy-consumption* & 54 & 22.3 & carbon dioxide** & 29 & 23.2 \\
\hline efficiency* & 53 & 18.6 & management & 29 & 16.4 \\
\hline climate-change** & 49 & 21.1 & emissions** & 28 & 17.1 \\
\hline optimization* & 49 & 17.3 & organic-matter & 28 & 17.1 \\
\hline impact** & 48 & 16.6 & $\mathrm{pH}$ & 28 & 19.4 \\
\hline China** & 46 & 19.3 & black carbon & 27 & 16.0 \\
\hline decomposition & 43 & 18.7 & financial development & 26 & 26.2 \\
\hline transport* & 40 & 21.1 & methane** & 26 & 16.2 \\
\hline dynamics & 39 & 15.9 & optical-properties & 25 & 16.7 \\
\hline dioxide emissions $* *$ & 38 & 25.1 & urbanization & 25 & 19.4 \\
\hline mechanisms & 36 & 22.0 & aerogels & 24 & 22.3 \\
\hline renewable energy* & 36 & 24.6 & climate change** & 24 & 16.5 \\
\hline environmental kuznets curve** & 35 & 29.2 & life-cycle assessment & 23 & 18.7 \\
\hline carbon emissions** & 34 & 22.4 & recovery & 23 & 20.0 \\
\hline economic-growth* & 34 & 19.4 & systems & 23 & 14.5 \\
\hline
\end{tabular}

Note: Contextually related terms are marked by the symbols * and $* *$. 
The conditional name of the cluster is "Energy consumption and climate change". Corresponding keywords: energy consumption, efficiency, optimization, transport, renewable energy, management, financial development, economic growth, urbanization, life-cycle assessment, $\mathrm{CO}_{2}$ emissions, environmental Kuznets curve, climate change.

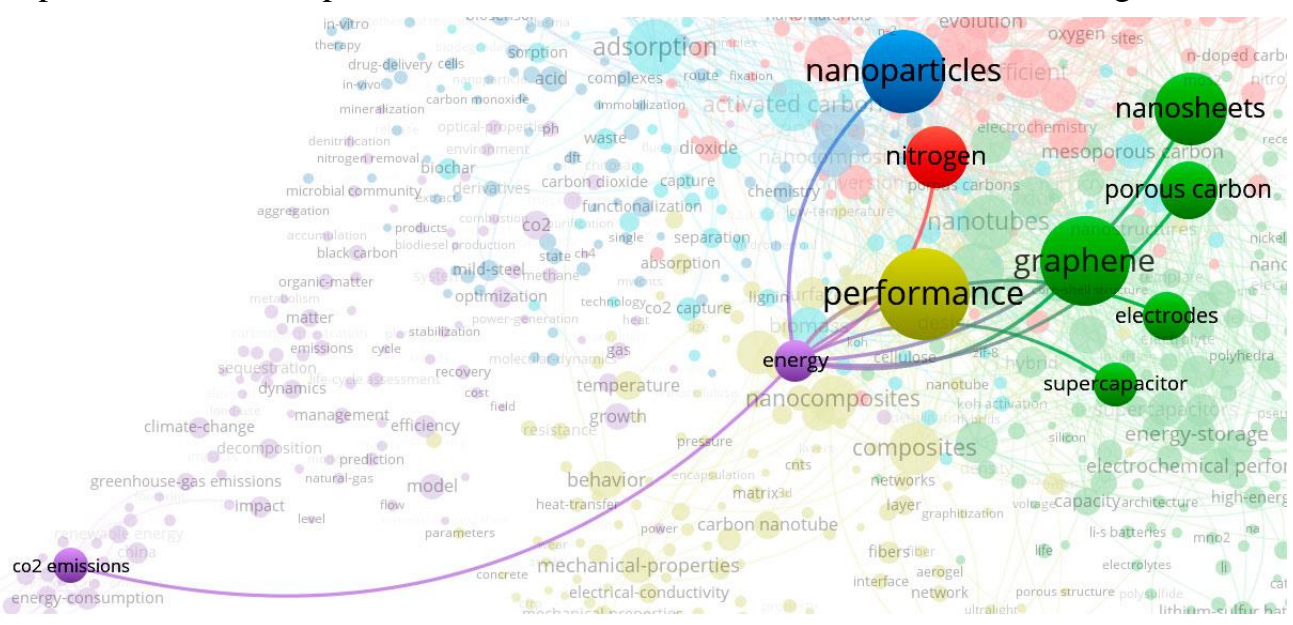

Fig. 11. Cluster 5. The main links of the term "energy" with the other terms

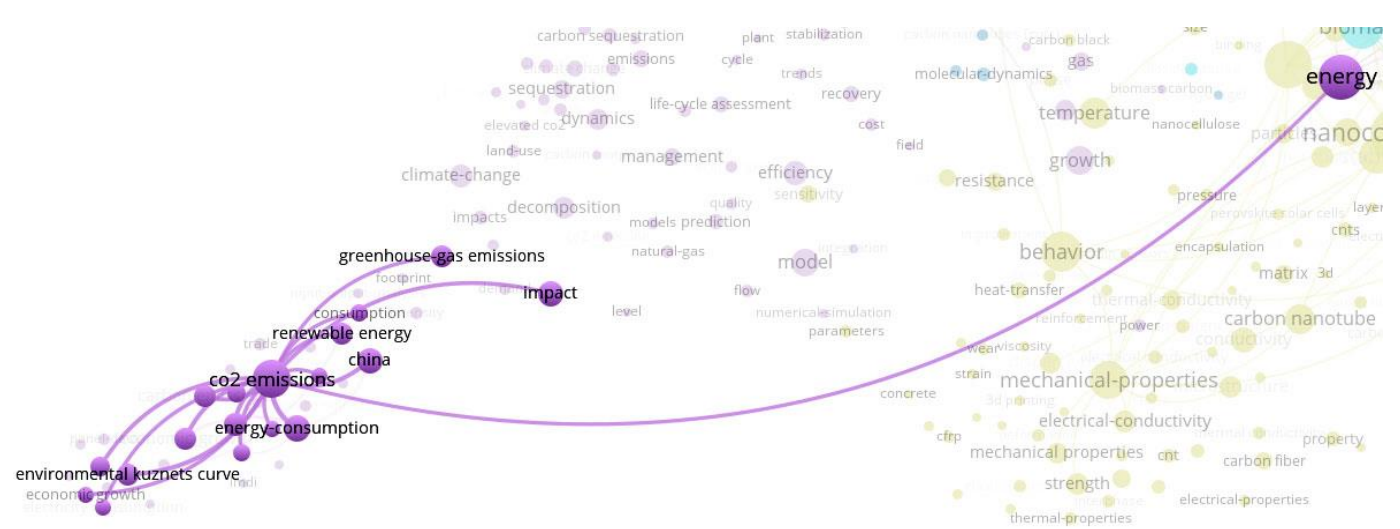

Fig. 12. Cluster 5. The main links of the term " $\mathrm{CO}_{2}$ emissions" with the other terms

This cluster is represented by the publications [33-37].

The results of the bibliometric analysis for the sixth cluster are presented in Table 9 and Fig. 13 and 14.

The $\mathbf{4 0}$ most frequent keywords within the Cluster 6

Table 9

and the average citations of publications associated with a keyword

\begin{tabular}{|l|c|c|l|c|c|}
\hline \multicolumn{1}{|c|}{ Label } & Occurrence & $\begin{array}{c}\text { Average } \\
\text { citations }\end{array}$ & \multicolumn{1}{|c|}{ Label } & Occurrence & $\begin{array}{c}\text { Average } \\
\text { citations }\end{array}$ \\
\hline \multicolumn{1}{|c|}{1} & 2 & 3 & & 5 & 6 \\
\hline nitrogen^ & 361 & 23.2 & electrocatalysis* & 88 & $\mathbf{2 6 . 0}$ \\
\hline water & 316 & 22.5 & iron & 86 & 20.9 \\
\hline facile synthesis & 254 & 23.5 & oxygen** & 85 & 23.0 \\
\hline efficient & 242 & 23.3 & CO $_{2}$ reduction & 84 & 25.7 \\
\hline reduction & 227 & 21.2 & electrocatalyst* & 82 & 23.0 \\
\hline catalysts* & 209 & 22.9 & hydrogen evolution** reaction & 79 & 25.3 \\
\hline oxygen reduction** reaction & 188 & $\mathbf{2 6 . 4}$ & active-sites & 77 & 25.9 \\
\hline degradation & 170 & 20.0 & sulfur & 75 & 21.7 \\
\hline metal-organic frameworks & 163 & 25.0 & TlO 2 & 74 & 17.7 \\
\hline oxidation** & 162 & 20.6 & construction & 71 & 24.9 \\
\hline
\end{tabular}


Table 9 continued

\begin{tabular}{|c|c|c|c|c|c|}
\hline 1 & 2 & 3 & 4 & 5 & 6 \\
\hline oxygen reduction** & 144 & 25.1 & dioxide & 69 & 21.4 \\
\hline catalyst* & 140 & 20.6 & oxygen evolution reaction & 67 & 24.3 \\
\hline electrocatalysts* & 137 & 27.3 & $\mathrm{CO}$ & 66 & 19.7 \\
\hline evolution & 136 & 24.8 & nitrogen-doped carbon^ ${ }^{\wedge}$ & 64 & 23.0 \\
\hline highly efficient & 132 & 23.0 & doped carbon & 62 & 23.8 \\
\hline conversion & 130 & 21.0 & hydrogen** & 62 & 20.7 \\
\hline hydrogen evolution** & 130 & 30.5 & carbon nitride $^{\wedge}$ & 58 & 27.3 \\
\hline metal-organic framework & 127 & 20.8 & $\mathrm{~g}^{-} \mathrm{C}_{3} \mathrm{~N}_{4}$ nanosheets $^{\wedge}$ & 58 & 22.9 \\
\hline photocatalysis* & 123 & 26.0 & graphitic carbon nitride $^{\wedge}$ & 58 & 23.5 \\
\hline $\mathrm{g}-\mathrm{C}_{3} \mathrm{~N}_{4}{ }^{\wedge}$ & 103 & 22.6 & N-doped carbon^^ & 58 & 22.5 \\
\hline
\end{tabular}

Note: Contextually related terms are marked by the symbols ${ }^{*}$ and ${ }^{* *}$. Nitrogen-related terms are marked by the symbol ${ }^{\wedge}$.

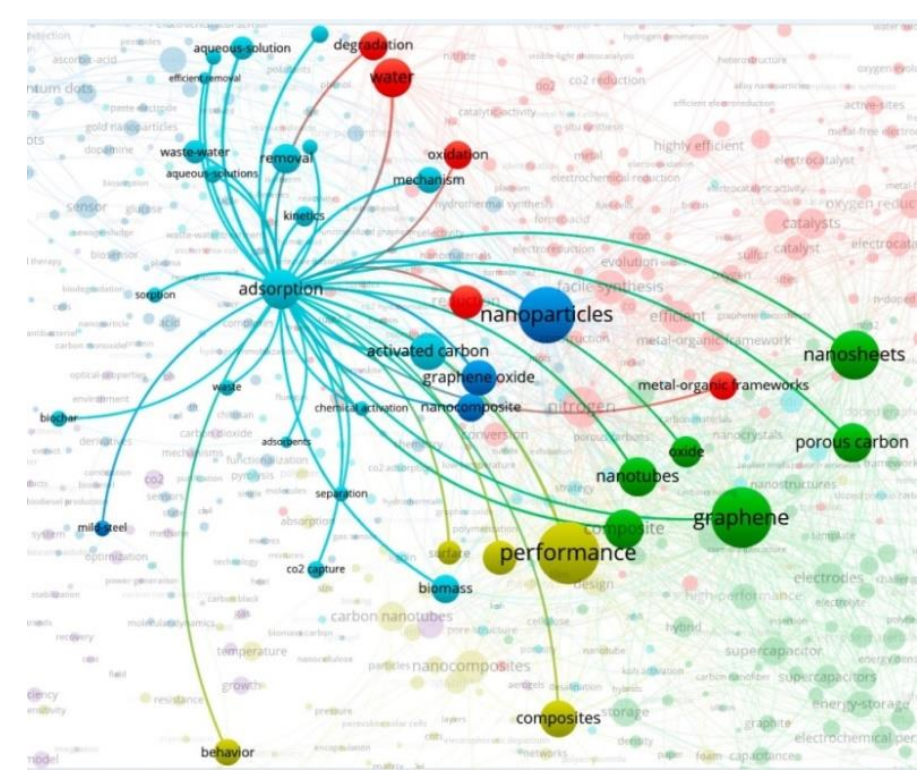

Fig. 13. Cluster 6. The main links of the term "adsorption" with the other terms

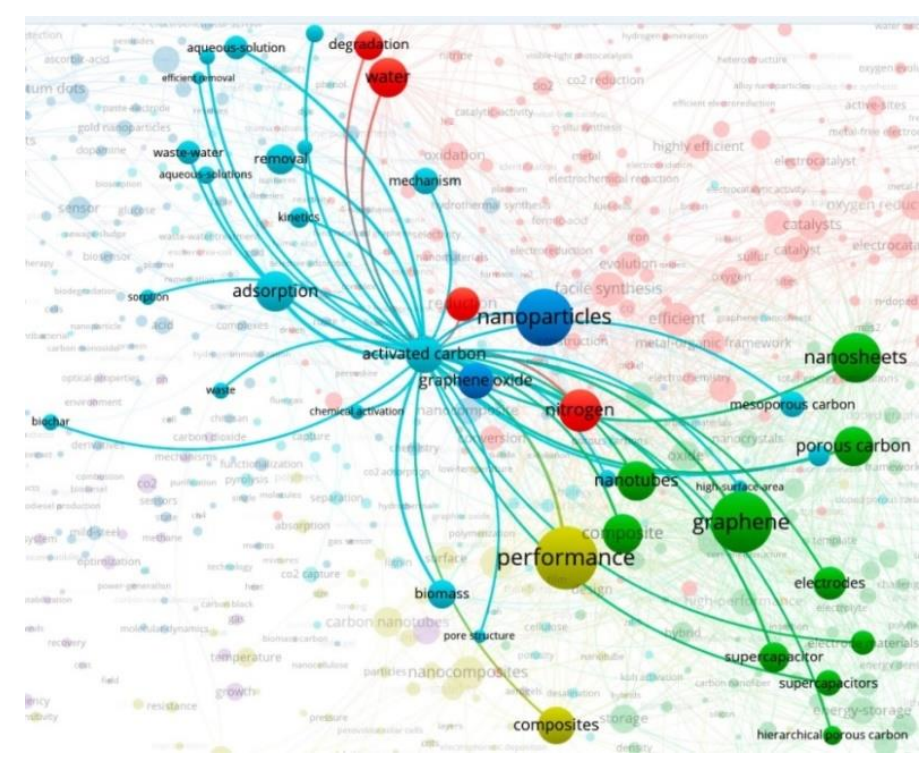

Fig. 14. Cluster 6. The main links of the term "activated carbon" with the other terms

This cluster is represented by the publications [38-43]. 
The conditional name of this cluster is "Adsorption and organic pollutants". Corresponding keywords: adsorption, activated carbon, mesoporous carbon, adsorbent, separation, sorption, chemical activation, highsurface-area, biomass, organic pollutants, wastewater treatment.

\section{Conclusions}

1. The brief bibliometric analysis of scientific publications on "Carbon" topic indicated a high level of applied research in the following Web of Science categories: Materials Science (Ceramics, Composites); Physical Chemistry; Condensed Matter Physics; Polymer Science; Nanoscience and Nanotechnology; Metallurgy and Metallurgical Engineering; Energy and Fuels. This knowledge can provide a foundation for the development of technology and the production of carbon-based materials.

2. The wide involvement of the world's leading economies in research on this topic was revealed. The good positions of Russia and the Russian Academy of Sciences in the research on carbon-based materials, the importance of the fuel and energy sector for the economy and the necessity of its transformation to achieve the United Nations Sustainable Development Goals make the subject of combining the tasks of hydrogen energy and carbon-based materials production relevant for applied and fundamental science.

3. The clustering method based on the cooccurrence of keywords yielded the six areas of research, which can be conventionally labelled as:

1) catalysis, hydrogen-production, nitrogendoped carbon;

2) graphite/graphene-based energy storage systems;

3) sensors and emissions based on carbon quantum dots;

4) nanocomposites and their physical properties;

5) energy consumption and climate change;

6) adsorption and organic pollutants.

The topic of hydrogen energy is well traced in the studies related to carbon-based materials.

The research area of hydrogen and graphite co-production is highly relevant, since it combines the needs of hydrogen energy development, graphite-based materials production (particularly for renewable energy purposes) and the objectives of $\mathrm{CO}_{2}$ emission reduction [44-50].

Especially important are the studies on the production of hydrogen by thermochemical pyrolysis of $\mathrm{CH}_{4}$ using a carbon catalyst and solar energy, which produces hydrogen and black carbon without generating $\mathrm{CO}_{2}[51-52]$.

Статья написана в рамках выполнения государственного задания (тема «ундаментальный базис инновационных технологий нефтяной и газовой промышленности (фундаментальные, поисковые и прикладные исследования)», № AАAА-А19-119013190038-2).

\section{References}

1. Staffell I., Scamman D., Velazquez Abad A. et al. The role of hydrogen and fuel cells in the global energy system // Energy \& Environmental Science. 2019. Vol. 12, No. 2. P. 463-491. https://doi.org/10.1039/c8ee01157e

2. The future of hydrogen. Report prepared by the IEA for the G20, Japan. 2019. $203 \mathrm{p}$. https://www.iea.org/reports/the-future-of-hydrogen (Accessed on 27.05.2021).

3. The hydrogen economy - a path towards low carbon development. SKOLKOVO Energy Centre, Moscow School of Management SKOLKOVO. 2019. 62 p. https://energy.skolkovo.ru/downloads/ documents/SEneC/Research/SKOLKOVO_EneC_Hydrogen-economy_Eng.pdf (Accessed on 27.05.2021).

4. van Eck N.J., Waltman L. Software survey: VOSviewer, a computer program for bibliometric mapping // Scientometrics. 2010. Vol. 84, No. 2. P. 523-538. https://doi.org/10.1007/s11192-009-0146-3 
5. Perianes-Rodriguez A., Waltman L., van Eck N.J. Constructing bibliometric networks: a comparison between full and fractional counting // Journal of Informetrics. 2016. Vol. 10, No. 4. P. 11781195. https://doi.org/10.1016/j.joi.2016.10.006

6. Zhu J., Hu L., Zhao $P$. et al. Recent advances in electrocatalytic hydrogen evolution using nanoparticles // Chemical Reviews. 2020. Vol. 120, No. 2. P. 851-918. https://doi.org/10.1021/ acs.chemrev.9b00248

7. Abdelhamid H.N. A review on hydrogen generation from the hydrolysis of sodium borohydride // International Journal of Hydrogen Energy. 2021. Vol. 46, No, 1. P. 726-765. https://doi.org/10.1016/ j.ijhydene.2020.09.186

8. Cao S., Low J., Yu J., Jaroniec M. Polymeric Photocatalysts Based on Graphitic Carbon Nitride // Advanced Materials. 2015. Vol. 27, No. 13. P. 2150-2176. https://doi.org/10.1002/adma.201500033

9. Ong W.-J., Tan L.-L., Ng Y.H. et al. Graphitic carbon nitride $\left(\mathrm{g}-\mathrm{C}_{3} \mathrm{~N}_{4}\right)$-based photocatalysts for artificial photosynthesis and environmental remediation: are we a step closer to achieving sustainability? // Chemical Reviews. 2016. Vol. 116, No. 12. P. 7159-7329. https://doi.org/10.1021/acs.chemrev.6b00075

10. Orooji Y., Ghanbari M., Amiri O., Salavati-Niasari M. Facile fabrication of silver iodide/graphitic carbon nitride nanocomposites by notable photo-catalytic performance through sunlight and antimicrobial activity // Journal of Hazardous Materials. 2020. Vol. 389. P. 122079. https://doi.org/10.1016/j.jhazmat.2020.122079

11. Wang Q., Domen $K$. Particulate photocatalysts for light-driven water splitting: mechanisms, challenges, and design strategies // Chemical Reviews. 2020. Vol. 120, No. 2. P. 919-985. https://doi.org/10.1021/acs.chemrev.9b00201

12. Li Z., Ji S., Liu Y., Cao X. et al. Well-Defined materials for heterogeneous catalysis: from nanoparticles to isolated single-atom sites // Chemical Reviews. 2020. Vol. 120, No. 2. P. 623-682. https://doi.org/10.1021/acs.chemrev.9b00311

13. Liu P., Gao S., Wang Y., Huang Y. et al. Carbon nanocages with N-doped carbon inner shell and $\mathrm{Co} / \mathrm{N}$-doped carbon outer shell as electromagnetic wave absorption materials //Chemical Engineering Journal. 2020. Vol. 381. P. 122653. https://doi.org/10.1016/j.cej.2019.122653

14. Wang H., Maiyalagan T., Wang X. Review on recent progress in nitrogen-doped graphene: synthesis, characterization, and its potential applications // ACS Catalysis. 2012. Vol. 2, No. 5. P. $781-794$. https://doi.org/10.1021/cs200652y

15. Wang Y., Ding B., Guo D. et al. A novel way to synthesize nitrogen and oxygen co-doped porous carbon for high performance supercapacitors // Microporous and Mesoporous Materials. 2019. Vol. 282. P. 114-120. https://doi.org/10.1016/j.micromeso.2019.03.031

16. Abdel Maksoud, M.I.A., Fahim, R.A., Shalan, A.E. et al. Advanced materials and technologies for supercapacitors used in energy conversion and storage: a review // Environmental Chemistry Letters. 2020. Vol. 19, No. 1. P. 375-439. https://doi.org/10.1007/s10311-020-01075-w

17. Pandolfo A.G., Hollenkamp A.F. Carbon properties and their role in supercapacitors // Journal of Power Sources. 2006. Vol. 157, No. 1. P. 11-27. https://doi.org/10.1016/j.jpowsour.2006.02.065

18. Yuan C., Wu H.B., Xie Y., Lou X.W.D. Mixed transition-metal oxides: design, synthesis, and energy-related applications // Angewandte Chemie International Edition. 2014. Vol. 53, No. 6. P. $1488-1504$. https://doi.org/10.1002/anie.201303971

19. Zhang L.L., Zhao X.S. Carbon-based materials as supercapacitor electrodes // Chemical Society Reviews. 2009. Vol. 38, No. 9. P. 2520-2531. https://doi.org/10.1039/b813846j 
20. Korkmaz S., Kariper I.A. Graphene and graphene oxide based aerogels: Synthesis, characteristics and supercapacitor applications // Journal of Energy Storage. 2020. Vol. 27. P. 101038. https://doi.org/10.1016/j.est.2019.101038

21. Li H., Liang J. Recent development of printed micro-supercapacitors: printable materials, printing technologies, and perspectives // Advanced Materials. 2020. Vol. 32, No. 3. P. 1805864. https://doi.org/10.1002/adma.201805864

22. Ahmadian-Fard-Fini S., Ghanbari D., Amiri O., Salavati-Niasari M. Electro-spinning of cellulose acetate nanofibers/Fe/carbon dot as photoluminescence sensor for mercury (II) and lead (II) ions // Carbohydrate Polymers. 2020. Vol. 229. P. 115428. https://doi.org/10.1016/j.carbpol.2019.115428

23. Qiao G., Liu L., Hao X. et al. Signal transduction from small particles: sulfur nanodots featuring mercury sensing, cell entry mechanism and in vitro tracking performance // Chemical Engineering Journal. 2020. Vol. 382. P. 122907. https://doi.org/10.1016/j.cej.2019.122907

24. Shen J., Zhu Y., Yang X. et al. Graphene quantum dots: emergent nanolights for bioimaging, sensors, catalysis and photovoltaic devices // Chemical Communications. 2012. Vol. 48, No. 31. P. 36863699. https://doi.org/10.1039/c2cc00110a

25. Wang Y., Hu A. Carbon quantum dots: synthesis, properties and applications // Journal of Materials Chemistry C. 2014. Vol. 2, No. 34. P. 6921-6939. https://doi.org/10.1039/c4tc00988f

26. Wu S., Min H., Shi W., Cheng $P$. Multicenter metal-organic framework-based ratiometric fluorescent sensors // Advanced Materials. 2020. Vol. 32, No. 3. P. 1805871. https://doi.org/10.1002/adma.201805871

27. Zhu S., Meng $Q$., Wang $L$. et al. Highly photoluminescent carbon dots for multicolor patterning, sensors, and bioimaging // Angewandte Chemie International Edition. 2013. Vol. 52, No. 14. P. 3953-3957. https://doi.org/10.1002/anie.201300519

28. Huang Z.-M., Zhang Y.-Z., Kotaki M., Ramakrishna S. A review on polymer nanofibers by electrospinning and their applications in nanocomposites // Composites Science and Technology. 2003. Vol. 63, No. 15. P.2223-2253. https://doi.org/10.1016/S0266-3538(03)00178-7

29. Liang C., Qiu H., Song P. et al. Ultra-light MXene aerogel/wood-derived porous carbon composites with wall-like "mortar/brick" structures for electromagnetic interference shielding //Science Bulletin. 2020. Vol. 65, No. 8. P. 616-622. https://doi.org/10.1016/j.scib.2020.02.009

30. Thostenson E.T., Ren Z.F., Chou T.W. Advances in the science and technology of carbon nanotubes and their composites: a review // Composites Science and Technology. 2001. Vol. 61, No. 13. P.1899-1912. https://doi.org/10.1016/S0266-3538(01)00094-X

31. Wei H., Wang H., Li A. et al. Multifunctions of polymer nanocomposites: environmental remediation, electromagnetic interference shielding, and sensing applications // ChemNanoMat. 2020. Vol. 6, No. 2. P. 174-184. https://doi.org/10.1002/cnma.201900588

32. Wong E.W., Sheehan P.E., Lieber C.M. Nanobeam mechanics: elasticity, strength, and toughness of nanorods and nanotubes // Science. 1997. Vol. 277, No. 5334. P. 1971-1975. https://doi.org/10.1126/science.277.5334.1971

33. Arouri M.E.H., Ben Youssef A., M'henni H., Rault C. Energy consumption, economic growth and $\mathrm{CO}_{2}$ emissions in Middle East and North African countries // Energy Policy. 2012. Vol. 45. P. 342-349. https://doi.org/10.1016/j.enpol.2012.02.042

34. Holmberg K., Andersson P., Erdemir A. Global energy consumption due to friction in passenger cars // Tribology International. 2012. Vol. 47. P. 221-234. https://doi.org/10.1016/j.triboint.2011.11.022 
35. Iram R., Zhang J., Erdogan S. et al. Economics of energy and environmental efficiency: evidence from OECD countries // Environmental Science and Pollution Research. 2020. Vol. 27, No. 4. P. 3858-3870. https://doi.org/10.1007/s11356-019-07020-x

36. Jalil A., Mahmud S.F. Environment Kuznets curve for $\mathrm{CO}_{2}$ emissions: a cointegration analysis for China // Energy Policy. 2009. Vol. 37, No. 12. P. 5167-5172. https://doi.org/10.1016/j.enpol.2009.07.044

37. Liu M., Ren X., Cheng C., Wang Z. The role of globalization in $\mathrm{CO}_{2}$ emissions: a semi-parametric panel data analysis for G7 // Science of the Total Environment. 2020. Vol. 718. P. 137379. https://doi.org/10.1016/j.scitotenv.2020.137379

38. Tang L., Yang G.-D., Zeng G.-M. et al. Synergistic effect of iron doped ordered mesoporous carbon on adsorption-coupled reduction of hexavalent chromium and the relative mechanism study // Chemical Engineering Journal. 2014. Vol. 239. P. 114-122. https://doi.org/10.1016/j.cej.2013.10.104

39. Zbair M., Bottlinger M., Ainassaari K. et al. Hydrothermal carbonization of argan nut shell: functional mesoporous carbon with excellent performance in the adsorption of bisphenol a and diuron // Waste Biomass Valorization. 2020. Vol. 11, No. 4. P. 1565-1584. https://doi.org/10.1007/s12649-018-00554-0

40. Chen M., Gио C., Нои S. et al. A novel Z-scheme $\mathrm{AgBr} / \mathrm{P}-\mathrm{g}-\mathrm{C}_{3} \mathrm{~N}_{4}$ heterojunction photocatalyst: excellent photocatalytic performance and photocatalytic mechanism for ephedrine degradation // Applied Catalysis B: Environmental. 2020. Vol. 266. https://doi.org/10.1016/j.apcatb.2020.118614

41. Dои M., Wang J., Gao B. et al. Photocatalytic difference of amoxicillin and cefotaxime under visible light by mesoporous $\mathrm{g}-\mathrm{C}_{3} \mathrm{~N}_{4}$ : mechanism, degradation pathway and DFT calculation // Chemical Engineering Journal. 2020. Vol. 383. P. 123134. https://doi.org/10.1016/j.cej.2019.123134

42. Rezakazemi M., Ebadi Amooghin A., Montazer-Rahmati M.M. et al. State-of-the-art membrane based $\mathrm{CO}_{2}$ separation using mixed matrix membranes (MMMs): an overview on current status and future directions // Progress in Polymer Science. 2014. Vol. 39, No. 5. P. 817-861. https://doi.org/ 10.1016/j.progpolymsci.2014.01.003

43. Zhou C., Lai C., Huang D. et al. Highly porous carbon nitride by supramolecular preassembly of monomers for photocatalytic removal of sulfamethazine under visible light driven // Applied Catalysis B: Environment. 2018. Vol. 220. P. 202-210. https://doi.org/10.1016/j.apcatb.2017.08.055

44. Dalapati G.K., Masudy-Panah S., Moakhar R.S. et al. Nanoengineered advanced materials for enabling hydrogen economy: functionalized graphene-incorporated cupric oxide catalyst for efficient solar hydrogen production // Global Challenges. 2020. Vol. 4, No. 3. P. 1900087. https://doi.org/ $10.1002 / \mathrm{gch} 2.201900087$

45. Donphai W., Phichairatanaphong O., Klysubun W., Chareonpanich M. Hydrogen and carbon allotrope production through methane cracking over $\mathrm{Ni} /$ bimodal porous silica catalyst: effect of nickel precursor // International Journal of Hydrogen Energy. 2018. P. 21798-21809. https://doi.org/ 10.1016/j.ijhydene.2018.10.049

46. Han K.-S., Kim J.-H., Kim H.-K., Hwang K.-T. Direct methane cracking using a mixed conducting ceramic membrane for production of hydrogen and carbon // International Journal of Hydrogen Energy. 2013. Vol. 38, No. 36. P.16133-16139. https://doi.org/10.1016/j.ijhydene.2013.10.027

47. Musamali R., Isa Y.M. Decomposition of methane to carbon and hydrogen: a catalytic perspective // Energy Technology. 2019. Vol. 7, No. 6. P. 1800593. https://doi.org/10.1002/ente.201800593

48. Sun C., Zheng X., Bai B. Hydrogen purification using nanoporous graphene membranes and its economic analysis // Chemical Engineering Science. 2019. Vol. 208. P. 115141. https://doi.org/10.1016/j.ces.2019.07.059 
49. Takenaka S., Shigeta Y., Tanabe E., Otsuka K. Methane decomposition into hydrogen and carbon nanofibers over supported Pd-Ni catalysts: Characterization of the catalysts during the reaction // Journal of Physical Chemistry B. 2004. Vol. 108, No. 23. P. 7656-7664. https://doi.org/10.1021/jp0377331

50. Tozzini V., Pellegrini V. Prospects for hydrogen storage in graphene // Physical Chemistry Chemical Physics. 2013. Vol. 15, No. 1. P. 80-89. https://doi.org/10.1039/c2cp42538f

51. Boretti $A$. There are hydrogen production pathways with better than green hydrogen economic and environmental costs // International Journal of Hydrogen Energy. 2021. Vol. 46, No. 6. P. 23988-23995. https://doi.org/10.1016/j.ijhydene.2021.04.182

52. Sánchez-Bastardo N., Schlögl R., Ruland H. Methane pyrolysis for zero-emission hydrogen production: A potential bridge technology from fossil fuels to a renewable and sustainable hydrogen economy // Industrial \& Engineering Chemistry Research. 2021. Vol. 60, No. 32. P. 11855-11881. https://doi.org/10.1021/acs.iecr.1c01679 


\title{
Краткий библиометрический анализ публикаций Web of Science по теме «Углерод» за 2019-2020 гr.
}

\author{
Б.Н. Чигарев \\ Институт проблем нефти и газа РАН, г. Москва \\ E-mail: bchigarev@ipng.ru
}

Аннотация. Дан краткий библиометрический анализ 5000 наиболее цитируемых научных публикаций, представленных в базе Web of Science по теме «Углерод» за 2019-2020 гг. Показано, что в исследования по данной тематике вовлечены ведущие мировые научные центры Китая, США, Индии, Южной Кореи, Японии, Германии, а также Российская академия наук. Доминировали следующие направления научных исследований: материаловедение, физическая химия, нанотехнологии, инженерная химия, прикладная физика, энергетика, электрохимия, экология, физика конденсированного состояния.

Методом кластеризации на основе совместной встречаемости ключевых слов авторов и системы Web of Science выявлено шесть направлений исследований: 1. катализ, получение водорода, углеродные материалы, легированные азотом; 2. накопители энергии на основе графита/графена; 3. сенсоры и излучатели на основе углеродных квантовых точек; 4. нанокомпозиты и их физические свойства; 5. потребление энергии и изменение климата; 6. адсорбция и органические загрязнители.

Выдвинуто предположение о перспективности исследований по совместному производству водорода и графита, которые могут объединить интересы развития водородной энергетики и производства новых материалов.

Ключевые слова: библиометрический анализ, Web of Science, наукометрия, углерод, графен, водород, катализ, нанокомпозиты, накопители энергии.

Для цитирования: Ччгарев Б.Н. Краткий библиометрический анализ публикаций Web of Science по теме «Углерод" за 2019-2020 гг. // Актуальные проблемы нефти и газа. 2021. Вып. 2(33). С. 76-100. https://doi.org/10.29222/ipng.2078-5712.2021-33.art6

\section{Литература}

1. Staffell I., Scamman D., Velazquez Abad A. et al. The role of hydrogen and fuel cells in the global energy system // Energy \& Environmental Science. 2019. Vol. 12, No. 2. P. 463-491. https://doi.org/10.1039/c8ee01157e

2. The future of hydrogen. Report prepared by the IEA for the G20, Japan. 2019. $203 \mathrm{p}$. https://www.iea.org/reports/the-future-of-hydrogen (Дата обращения 27.05.2021).

3. The hydrogen economy - a path towards low carbon development. SKOLKOVO Energy Centre, Moscow School of Management SKOLKOVO. 2019. 62 p. https://energy.skolkovo.ru/downloads/ documents/SEneC/Research/SKOLKOVO_EneC_Hydrogen-economy_Eng.pdf (Дата обращения 27.05.2021).

4. van Eck N.J., Waltman L. Software survey: VOSviewer, a computer program for bibliometric mapping // Scientometrics. 2010. Vol. 84, No. 2. P. 523-538. https://doi.org/10.1007/s11192-009-0146-3

5. Perianes-Rodriguez A., Waltman L., van Eck N.J. Constructing bibliometric networks: a comparison between full and fractional counting // Journal of Informetrics. 2016. Vol. 10, No. 4. P. 11781195. https://doi.org/10.1016/j.joi.2016.10.006 
6. Zhu J., $Н u$ L., Zhao $P$. et al. Recent advances in electrocatalytic hydrogen evolution using nanoparticles // Chemical Reviews. 2020. Vol. 120, No. 2. P. 851-918. https://doi.org/10.1021/ acs.chemrev.9b00248

7. Abdelhamid H.N. A review on hydrogen generation from the hydrolysis of sodium borohydride // International Journal of Hydrogen Energy. 2021. Vol. 46, No, 1. P. 726-765. https://doi.org/10.1016/ j.ijhydene.2020.09.186

8. Cao S., Low J., Yu J., Jaroniec M. Polymeric Photocatalysts Based on Graphitic Carbon Nitride // Advanced Materials. 2015. Vol. 27, No. 13. P. 2150-2176. https://doi.org/10.1002/adma.201500033

9. Ong W.-J., Tan L.-L., Ng Y.H. et al. Graphitic carbon nitride $\left(\mathrm{g}^{-} \mathrm{C}_{3} \mathrm{~N}_{4}\right)$-based photocatalysts for artificial photosynthesis and environmental remediation: are we a step closer to achieving sustainability? // Chemical Reviews. 2016. Vol. 116, No. 12. P. 7159-7329. https://doi.org/10.1021/acs.chemrev.6b00075

10. Orooji Y., Ghanbari M., Amiri O., Salavati-Niasari M. Facile fabrication of silver iodide/graphitic carbon nitride nanocomposites by notable photo-catalytic performance through sunlight and antimicrobial activity // Journal of Hazardous Materials. 2020. Vol. 389. P. 122079. https://doi.org/10.1016/j.jhazmat.2020.122079

11. Wang Q., Domen K. Particulate photocatalysts for light-driven water splitting: mechanisms, challenges, and design strategies // Chemical Reviews. 2020. Vol. 120, No. 2. P. 919-985. https://doi.org/10.1021/acs.chemrev.9b00201

12. Li Z., Ji S., Liu Y., Cao X. et al. Well-Defined materials for heterogeneous catalysis: from nanoparticles to isolated single-atom sites // Chemical Reviews. 2020. Vol. 120, No. 2. P. 623-682. https://doi.org/10.1021/acs.chemrev.9b00311

13. Liu P., Gao S., Wang Y., Huang Y. et al. Carbon nanocages with N-doped carbon inner shell and $\mathrm{Co} / \mathrm{N}$-doped carbon outer shell as electromagnetic wave absorption materials // Chemical Engineering Journal. 2020. Vol. 381. P. 122653. https://doi.org/10.1016/j.cej.2019.122653

14. Wang $H$., Maiyalagan $T$., Wang $X$. Review on recent progress in nitrogen-doped graphene: synthesis, characterization, and its potential applications // ACS Catalysis. 2012. Vol. 2, No. 5. P. 781-794. https://doi.org/10.1021/cs200652y

15. Wang Y., Ding B., Guo D., et al. A novel way to synthesize nitrogen and oxygen co-doped porous carbon for high performance supercapacitors // Microporous and Mesoporous Materials. 2019. Vol. 282. P. 114-120. https://doi.org/10.1016/j.micromeso.2019.03.031

16. Abdel Maksoud, M.I.A., Fahim, R.A., Shalan, A.E. et al. Advanced materials and technologies for supercapacitors used in energy conversion and storage: a review // Environmental Chemistry Letters. 2020. Vol. 19, No. 1. P. 375-439. https://doi.org/10.1007/s10311-020-01075-w

17. Pandolfo A.G., Hollenkamp A.F. Carbon properties and their role in supercapacitors // Journal of Power Sources. 2006. Vol. 157, No. 1. P. 11-27. https://doi.org/10.1016/j.jpowsour.2006.02.065

18. Yuan C., Wu H.B., Xie Y., Lou X.W.D. Mixed transition-metal oxides: design, synthesis, and energy-related applications // Angewandte Chemie International Edition. 2014. Vol. 53, No. 6. P. 1488-1504. https://doi.org/10.1002/anie.201303971

19. Zhang L.L., Zhao X.S. Carbon-based materials as supercapacitor electrodes // Chemical Society Reviews. 2009. Vol. 38, No. 9. P. 2520-2531. https://doi.org/10.1039/b813846j

20. Korkmaz S., Kariper I.A. Graphene and graphene oxide based aerogels: Synthesis, characteristics and supercapacitor applications // Journal of Energy Storage. 2020. Vol. 27. P. 101038. https://doi.org/10.1016/j.est.2019.101038 
21. Li H., Liang J. Recent development of printed micro-supercapacitors: printable materials, printing technologies, and perspectives // Advanced Materials. 2020. Vol. 32, No. 3. P. 1805864. https://doi.org/10.1002/adma.201805864

22. Ahmadian-Fard-Fini S., Ghanbari D., Amiri O., Salavati-Niasari M. Electro-spinning of cellulose acetate nanofibers/Fe/carbon dot as photoluminescence sensor for mercury (II) and lead (II) ions // Carbohydrate Polymers. 2020. Vol. 229. P. 115428. https://doi.org/10.1016/j.carbpol.2019.115428

23. Qiao G., Liu L., Hao X. et al. Signal transduction from small particles: sulfur nanodots featuring mercury sensing, cell entry mechanism and in vitro tracking performance // Chemical Engineering Journal. 2020. Vol. 382. P. 122907. https://doi.org/10.1016/j.cej.2019.122907

24. Shen J., Zhu Y., Yang $X$. et al. Graphene quantum dots: emergent nanolights for bioimaging, sensors, catalysis and photovoltaic devices // Chemical Communications. 2012. Vol. 48, No. 31. P. 36863699. https://doi.org/10.1039/c2cc00110a

25. Wang Y., Hu A. Carbon quantum dots: synthesis, properties and applications // Journal of Materials Chemistry C. 2014. Vol. 2, No. 34. P. 6921-6939. https://doi.org/10.1039/c4tc00988f

26. Wu S., Min H., Shi W., Cheng $P$. Multicenter metal-organic framework-based ratiometric fluorescent sensors // Advanced Materials. 2020. Vol. 32, No. 3. P. 1805871. https://doi.org/10.1002/adma.201805871

27. Zhu S., Meng Q., Wang L. et al. Highly photoluminescent carbon dots for multicolor patterning, sensors, and bioimaging // Angewandte Chemie International Edition. 2013. Vol. 52, No. 14. P. 3953-3957. https://doi.org/10.1002/anie.201300519

28. Huang Z.-M., Zhang Y.-Z., Kotaki M., Ramakrishna S. A review on polymer nanofibers by electrospinning and their applications in nanocomposites // Composites Science and Technology. 2003. Vol. 63, No. 15. P.2223-2253. https://doi.org/10.1016/S0266-3538(03)00178-7

29. Liang C., Qiu H., Song P. et al. Ultra-light MXene aerogel/wood-derived porous carbon composites with wall-like "mortar/brick" structures for electromagnetic interference shielding // Science Bulletin. 2020. Vol. 65, No. 8. P. 616-622. https://doi.org/10.1016/j.scib.2020.02.009

30. Thostenson E.T., Ren Z.F., Chou T.W. Advances in the science and technology of carbon nanotubes and their composites: a review // Composites Science and Technology. 2001. Vol. 61, No. 13. P.1899-1912. https://doi.org/10.1016/S0266-3538(01)00094-X

31. Wei H., Wang H., Li A. et al. Multifunctions of polymer nanocomposites: environmental remediation, electromagnetic interference shielding, and sensing applications // ChemNanoMat. 2020. Vol. 6, No. 2. P. 174-184. https://doi.org/10.1002/cnma.201900588

32. Wong E.W., Sheehan P.E., Lieber C.M. Nanobeam mechanics: elasticity, strength, and toughness of nanorods and nanotubes // Science. 1997. Vol. 277, No. 5334. P. 1971-1975. https://doi.org/10.1126/science.277.5334.1971

33. Arouri M.E.H., Ben Youssef A., M'henni H., Rault C. Energy consumption, economic growth and $\mathrm{CO}_{2}$ emissions in Middle East and North African countries // Energy Policy. 2012. Vol. 45. P. 342-349. https://doi.org/10.1016/j.enpol.2012.02.042

34. Holmberg K., Andersson P., Erdemir A. Global energy consumption due to friction in passenger cars // Tribology International. 2012. Vol. 47. P. 221-234. https://doi.org/10.1016/j.triboint.2011.11.022

35. Iram R., Zhang J., Erdogan S. et al. Economics of energy and environmental efficiency: evidence from OECD countries // Environmental Science and Pollution Research. 2020. Vol. 27, No. 4. P. 3858-3870. https://doi.org/10.1007/s11356-019-07020-x 
36. Jalil A., Mahmud S.F. Environment Kuznets curve for $\mathrm{CO}_{2}$ emissions: a cointegration analysis for China // Energy Policy. 2009. Vol. 37, No. 12. P. 5167-5172. https://doi.org/10.1016/j.enpol.2009.07.044

37. Liu M., Ren X., Cheng C., Wang Z. The role of globalization in $\mathrm{CO}_{2}$ emissions: a semi-parametric panel data analysis for G7 // Science of the Total Environment. 2020. Vol. 718. P. 137379. https://doi.org/10.1016/j.scitotenv.2020.137379

38. Tang L., Yang G.-D., Zeng G.-M. et al. Synergistic effect of iron doped ordered mesoporous carbon on adsorption-coupled reduction of hexavalent chromium and the relative mechanism study // Chemical Engineering Journal. 2014. Vol. 239. P. 114-122. https://doi.org/10.1016/j.cej.2013.10.104

39. Zbair M., Bottlinger M., Ainassaari K. et al. Hydrothermal carbonization of argan nut shell: functional mesoporous carbon with excellent performance in the adsorption of bisphenol a and diuron // Waste Biomass Valorization. 2020. Vol. 11, No. 4. P. 1565-1584. https://doi.org/10.1007/s12649-018-00554-0

40. Chen M., Gио C., Нои S. et al. A novel Z-scheme $\mathrm{AgBr} / \mathrm{P}-\mathrm{g}-\mathrm{C}_{3} \mathrm{~N}_{4}$ heterojunction photocatalyst: excellent photocatalytic performance and photocatalytic mechanism for ephedrine degradation // Applied Catalysis B: Environmental. 2020. Vol. 266. https://doi.org/10.1016/j.apcatb.2020.118614

41. Dou M., Wang J., Gao B. et al. Photocatalytic difference of amoxicillin and cefotaxime under visible light by mesoporous $\mathrm{g}-\mathrm{C}_{3} \mathrm{~N}_{4}$ : mechanism, degradation pathway and DFT calculation // Chemical Engineering Journal. 2020. Vol. 383. P. 123134. https://doi.org/10.1016/j.cej.2019.123134

42. Rezakazemi M., Ebadi Amooghin A., Montazer-Rahmati M.M. et al. State-of-the-art membrane based $\mathrm{CO}_{2}$ separation using mixed matrix membranes (MMMs): an overview on current status and future directions // Progress in Polymer Science. 2014. Vol. 39, No. 5. P. 817-861. https://doi.org/ 10.1016/j.progpolymsci.2014.01.003

43. Zhou C., Lai C., Huang D. et al. Highly porous carbon nitride by supramolecular preassembly of monomers for photocatalytic removal of sulfamethazine under visible light driven // Applied Catalysis B: Environment. 2018. Vol. 220. P. 202-210. https://doi.org/10.1016/j.apcatb.2017.08.055

44. Dalapati G.K., Masudy-Panah S., Moakhar R.S. et al. Nanoengineered advanced materials for enabling hydrogen economy: functionalized graphene-incorporated cupric oxide catalyst for efficient solar hydrogen production // Global Challenges. 2020. Vol. 4, No. 3. P. 1900087. https://doi.org/ $10.1002 / \mathrm{gch} 2.201900087$

45. Donphai W., Phichairatanaphong O., Klysubun W., Chareonpanich M. Hydrogen and carbon allotrope production through methane cracking over Ni/bimodal porous silica catalyst: effect of nickel precursor // International Journal of Hydrogen Energy. 2018. P. 21798-21809. https://doi.org/ 10.1016/j.ijhydene.2018.10.049

46. Han K.-S., Kim J.-H., Kim H.-K., Hwang K.-T. Direct methane cracking using a mixed conducting ceramic membrane for production of hydrogen and carbon // International Journal of Hydrogen Energy. 2013. Vol. 38, No. 36. P.16133-16139. https://doi.org/10.1016/j.ijhydene.2013.10.027

47. Musamali R., Isa Y.M. Decomposition of methane to carbon and hydrogen: a catalytic perspective // Energy Technology. 2019. Vol. 7, No. 6. P. 1800593. https://doi.org/10.1002/ente.201800593

48. Sun C., Zheng X., Bai B. Hydrogen purification using nanoporous graphene membranes and its economic analysis // Chemical Engineering Science. 2019. Vol. 208. P. 115141. https://doi.org/10.1016/j.ces.2019.07.059

49. Takenaka S., Shigeta Y., Tanabe E., Otsuka K. Methane decomposition into hydrogen and carbon nanofibers over supported Pd-Ni catalysts: Characterization of the catalysts during the reaction // Journal of Physical Chemistry B. 2004. Vol. 108, No. 23. P. 7656-7664. https://doi.org/10.1021/jp0377331 
50. Tozzini V., Pellegrini V. Prospects for hydrogen storage in graphene // Physical Chemistry Chemical Physics. 2013. Vol. 15, No. 1. P. 80-89. https://doi.org/10.1039/c2cp42538f

51. Boretti $A$. There are hydrogen production pathways with better than green hydrogen economic and environmental costs // International Journal of Hydrogen Energy. 2021. Vol. 46, No. 6. P. 23988-23995. https://doi.org/10.1016/j.jijhydene.2021.04.182

52. Sánchez-Bastardo $N$., Schlögl R., Ruland $H$. Methane pyrolysis for zero-emission hydrogen production: A potential bridge technology from fossil fuels to a renewable and sustainable hydrogen economy // Industrial \& Engineering Chemistry Research. 2021. Vol. 60, No. 32. P. 11855-11881. https://doi.org/10.1021/acs.iecr.1c01679 